IZA DP No. 5669

The Effect of Product Market Competition on Job Instability

Ainhoa Aparicio

April 2011 


\title{
The Effect of Product Market Competition on Job Instability
}

\author{
Ainhoa Aparicio \\ Collegio Carlo Alberto \\ and IZA
}

Discussion Paper No. 5669

April 2011

IZA

P.O. Box 7240

53072 Bonn

Germany

Phone: +49-228-3894-0

Fax: +49-228-3894-180

E-mail: iza@iza.org

Any opinions expressed here are those of the author(s) and not those of IZA. Research published in this series may include views on policy, but the institute itself takes no institutional policy positions.

The Institute for the Study of Labor (IZA) in Bonn is a local and virtual international research center and a place of communication between science, politics and business. IZA is an independent nonprofit organization supported by Deutsche Post Foundation. The center is associated with the University of Bonn and offers a stimulating research environment through its international network, workshops and conferences, data service, project support, research visits and doctoral program. IZA engages in (i) original and internationally competitive research in all fields of labor economics, (ii) development of policy concepts, and (iii) dissemination of research results and concepts to the interested public.

IZA Discussion Papers often represent preliminary work and are circulated to encourage discussion. Citation of such a paper should account for its provisional character. A revised version may be available directly from the author. 
IZA Discussion Paper No. 5669

April 2011

\begin{abstract}

\section{The Effect of Product Market Competition on Job Instability}

This paper assesses the impact of product market competition on job instability as proxied by the use of fixed-term labor contracts. Using both worker data from the Spanish Labor Force Survey and firm data from the Spanish Business Strategies Survey, I show that job instability rises with competition. In particular, a one standard deviation increase in competition in an economic sector decreases the probability that a fixed-term worker gets an open-ended contract within that sector in a given year by more than $30 \%$. The effect is identified by means of exogenous shifts in competition brought about by changes in legislation.
\end{abstract}

JEL Classification: J24, M51, C41, C33, C35, J6, L1

Keywords: $\quad$ product market competition, fixed-term employment, labor contract

Corresponding author:

Ainhoa Aparicio

Collegio Carlo Alberto

Via Real Collegio 30

Moncalieri (TO) 10024

Italy

E-mail: ainhoa.aparicio@carloalberto.org

\footnotetext{
* I would like to thank Libertad Gonzlez for her invaluable advice and support. This paper has benefited from comments by, and discussions with Thijs Van Rens, Kurt Schmidheiny, Gilles Saint Paul, Maria Guadalupe, Vicente Cuat, Maia Gell and Sergi Jimnez. I would also like to thank conference participants of the Symposium of Economic Analysis, ESPE and EEA-ESEM as well as seminar audiences at Universitat Pompeu Fabra and Toulouse School of Economics.
} 


\section{Introduction}

Workers hired under a fixed-term in place of an open-ended labor contract present worse unemployment prospects as well as stronger perception of job instability, which ultimately determines household decisions. The existing studies on the use of fixed-term contracts focus on the role of individual characteristics, labor histories and institutions in determining the type of labor contract that firms offer to workers, but they omit the impact of product market competition faced by firms. However, competition has been shown to have a significant influence on firms' decisions about the labor market. In particular, previous literature has found that product market competition affects not only employment and wage levels ${ }^{1}$, but also wage inequality, returns to skill, executives' incentives, workers' training and discrimination, among others. In this paper, product market competition is shown to increase job instability as measured by the intensity of use of fixed-term contracts. Accounting for the effect of product market competition allows to explain a substantial part of the variation in the use of fixed-term versus open-ended labor contracts. Therefore, the big changes in the level of competition in recent years as a result of globalization, market integration and privatization are useful to explain the proliferation of fixed-term contracts.

In most European countries, labor contracts are either fixed-term (temporary) or openended (permanent). Fixed-term contracts are characterized by having a pre-determined duration, negligible firing costs and a maximum for the amount of time a worker can be sequentially hired under that type of contract. After that period expires, the firm has to discard the worker or offer her an open-ended position. In contrast, open-ended contracts have unlimited duration and higher firing costs. Then, the use of fixed-term contracts is a key indicator of job instability because they are not only associated with the actual probability of becoming unemployed, but also with a worker's perception of instability

\footnotetext{
${ }^{1}$ See for instance Nicoletti \& Scarpetta (2005), Griffith, Harrison and Macartney (2007) and Fiori et al. (2007) for empirical country-level analysis on the incidence of product market competition on employment and wages. For theoretical studies on the interactions between product market competition, employment and wages, see Blanchard and Giavazzi (2003) and Ebell and Haefke (2009).
} 
while employed which connects it directly to workers' welfare. Throughout this paper, I focus on type of labor contract as an observable measure of job instability and complement the analysis with the study of sector switches and transitions to unemployment.

The use of fixed-term contracts in Spain is the highest in Europe. Employment relationships in that country traditionally start with a fixed-term contract and then, employers take the decision on whether to convert the fixed-term contract into an open-ended contract or not. Hence, the vast majority of workers are affected by fixed-term contracts at some point in their working lifes. Moreover, having a fixed-term contract is the main determinant of losing a job in Spain during the current economic crisis. In fact, this type of labor contract is found to be much more relevant as a predictor of job loss than educational attainment, age, gender or nationality ${ }^{2}$. Additionally, De la Rica and Iza (2005) show that holding a fixed-term contract leads to a delay in marriage and parenthood. Thus, the quantitative and qualitative importance of type of labor contract in Spain justifies its use as a benchmark case.

After the creation of fixed-term contracts in 1984, there was a rapid increase in the proportion of fixed-term over total salaried workers in Spain. This proportion stabilized around 1992. Since then, the incidence of fixed-term contracts has remained relatively stable at around one third of salaried workers ${ }^{3}$ (see Figure 1), despite the fact that the Spanish government has promoted several laws to reduce their use. Only under the recent economic crisis, the incidence of fixed-term contracts has decreased as a consequence of the overall reduction in employment, which has affected mainly fixed-term workers. Hence, the understanding of the determinants of the use of fixed-term contracts is of essential policy interest.

The apparent stability of the overall proportion of fixed-term contracts does not hold, however, when disaggregating the proportion of fixed-term contracts across sectors. Figure

\footnotetext{
${ }^{2}$ These conclusions are reflected in the quarterly bulletins of the Spanish Labor Observatory of the Crisis (Observatorio Laboral de la Crisis): http://www.fedea.es/observatorio/

${ }^{3}$ The average proportion of fixed-term workers over total number of contracted workers in the European Union is $15 \%$, according to data from Eurostat.
} 
2 displays the evolution of the proportion of fixed-term contracts over time for five different sectors, corresponding to the key percentiles of the distribution of the proportion of fixedterm contracts by sector. The sectors with the lowest and highest proportion of fixedterm over total workers are mining (10\%) and agriculture (60\%). Moreover, not only is there considerable variation in the average across sectors, there is also great variation in their time trends. For instance, between 1996 and 1997, while the recycling and medical equipment sectors experience a rise, the electronic material sector suffers a decrease in the proportion of fixed-term workers. This indicates that there is likely to be some factor varying across sectors and over time that affects the use of fixed-term contracts.

In this paper, I show that product market competition is an important factor behind the observed variation across sectors because product market competition has a causal impact on job instability as measured by the incidence of fixed-term contracts. Empirical results show that a one standard deviation increase in the level of competition reduces the probability that a fixed-term worker becomes open-ended within a sector in a given year by more than $30 \%$, and it increases the probability of becoming unemployed by more than $35 \%$. Additionally, I find that the elimination of barriers to entry such that one market transitions from legal monopoly to free entry induces a decrease of $12 \%$ in the probability of becoming open-ended within a sector in a given year for workers hired under fixed-term contracts. These results are robust to the use of different individual databases as well as firm level data. They are also consistent across different measures of competition.

This paper is related to the literature on the impact of product market competition on labor market outcomes. It has been shown that product market competition induces certain improvements in the functioning of the labor market, mainly in outcomes related with efficiency. In particular, product market competition ${ }^{4}$ boosts productivity

\footnotetext{
${ }^{4}$ The concepts and measures of product market competition differ greatly across studies. Griffith (2001) uses the implementation of the European Union Single Market Program as a quasi-experiment. Bertrand and Kramarz (2002) make use of changes in entry regulation as a source of increases in competition. Cuñat and Guadalupe (2006) study the effect of foreign competition as measured by import penetration. Levine, Levkov and Rubinstein (2008) take advantage of bank deregulation to identify an exogenous intensification of competition. Heyman, Svaleryd and Vlachos (2008) use firms' takeovers as a determinant of increases in competition. Bertrand (2004) makes use of changes in exchange-rate
} 
(Griffith, 2001), increases employment (Bertrand and Kramarz, 2002), rises executive incentives (Cuñat and Guadalupe, 2006), induces more on workplace training (Bassanini and Brunello, 2010), reduces gender discrimination (Heyman et al., 2008) and lowers race discrimination (Levine et al., 2008). In contrast, product market competition is thought to have negative effects on labor market outcomes related to workers' welfare and inequality. Specifically, competition has been found to decrease wage insurance against the business cycle provided to workers by firms (Bertrand, 2004) and increase wage inequality (Guadalupe, 2007). The closest paper to this one is Goldberg, Tracy and Aaronson (1999). They study whether exchange-rate movements as inductors of changes in the competitiveness of US firms have an impact on job turnover as measured by the probability of job switching and the probability of industry switching. Their findings suggest no significant effect of dollar movements on job turnover. This paper is, to the best of my knowledge, the first to empirically address the effect of product market competition on job instability as measured by the type of labor contract as well as the first to study the interactions of type of labor contracts and product market competition in the context of a theoretical model.

In order to illustrate the importance of the question addressed here, I first propose a theoretical model that sheds light on the channels through which product market competition may affect transitions from fixed-term to open-ended employment. When deciding on which workers to make open-ended and which ones to keep as fixed-term, firms face a trade off between higher productivity and higher firing costs (open-ended contracts allow the firm to keep the most productive workers but makes separation more costly) ${ }^{5}$. The degree to which firms are willing to pay more aggregate severance pay in exchange for higher productivity depends on the prevailing level of competition. This explains why

movements to generate exogenous variation in import competition. Guadalupe (2007) applies two quasiexperiments based on an exogenous and sudden appreciation of the Pound and the implementation of the European Union Single Market Program, respectively.

${ }^{5}$ This trade off has been studied by Blanchard and Landier (2002). They claim that the difference in firing costs between open-ended and fixed-term contracts is the reason why firms may be willing to sacrifice gains in productivity learned through screening. 
competition may have an impact on the type of contracts used by a firm. This model is, to the best of my knowledge, the first one to combine product market competition and type of labor contract. It takes into account the different dimensions of product market competition, namely, market size, product differentiation and entry cost, and includes important aspects of fixed-term contracts like: (i) their usefulness as screening device, (ii) the fact that fixed-term workers face a higher probability of separation from the firm, and (iii) the difference in dismissal costs between fixed-term and open-ended contracts. The model predicts that in equilibrium, when the number of transitions to open-ended contracts is lower (higher) than the value arising under perfect competition, more competition induces more (less) transitions. This can be interpreted as product market competition moving the transition rate towards some intermediate efficient value. Thus, empirical analysis is needed to clarify which is the direction of the impact of product market competition on the use of fixed-term and open-ended contracts.

The empirical estimation focuses on three related outcomes. Firstly, transitions from fixed-term to open-ended contracts, which are particularly relevant because the vast majority of open-ended contracts are acquired only after a period under a fixed-term contract in the same firm. Güell and Petrongolo (2007) highlight that more than 90\% of new labor contracts registered in the Spanish National Employment Office are fixed-term contracts and Bover and Gomez (2004) report that exit rates from unemployment into fixed-term employment are ten times larger than exit rates into open-ended employment. Secondly, the estimation of transitions from fixed-term to open-ended contracts is complemented by an specification where the dependent variable is the proportion of fixed-term workers in the firm. Thirdly, sector switches are also studied. Fourthly, transitions to unemployment constitute a complementary object of interest.

The causal impact of product market competition on job instability is identified by means of exogenous changes in legislation. In particular, I apply an instrumental variable strategy based on changes in anti-competitive legislation in key input sectors. Additionally, I propose a quasi-natural experiment based on the implementation of the European 
Union Directives enhancing competition in Spain.

The remainder of the paper proceeds as follows. Section 2 presents the theoretical model that relates product market competition and transitions from fixed-term to openended employment and which provides a framework for the empirical analysis. Section 3 presents the empirical methodology used, i.e., the instrumental variable approach and the quasi-experiment. Section 4 describes the databases in use, the construction of the variables and the sample included in the analysis. Section 5 includes the empirical results. Section 6 concludes.

\section{Theoretical model}

\subsection{Setup}

I propose a model that illustrates how the type of labor contract may be affected by product market competition. I focus on the use of fixed-term contracts as workers' screening devices. The possibility of using fixed-term contracts as a mechanism to screen the worker induces interactions of competition and type of contracts different from the ones between competition and employment.

This partial-equilibrium model interacts the product and labor markets through the cost function of the firm in the spirit of Raith (2003). There are two periods. In the first period, workers are hired under fixed-term contracts, production takes place, the firm learns the productivity of its matches with workers, firms compete in prices and profit realizes. In the second period, the firm decides which workers to make open-ended and which ones to keep as fixed-term, exogenous separations occur, production takes place, firms compete in prices and second period profit realizes.

\subsubsection{Product market}

The product market is modelled à la Salop. Firms are positioned symmetrically around a circle of circumference one. The circle is populated by consumers with a mass of $m$. Each 
consumer buys one unit of the good. Consumers prefer the variety closer to them and they incur in a transportation cost which is a proportion $d$ of the distance between them and the firm they buy from. This transportation cost represents product differentiation. Firms enter the market freely up to the payment of a fixed cost, F. Labor is the only production input. The unit cost is defined as $c_{t}=\bar{c}-a_{t}$ for each firm, where $t$ reflects the period. This implies that in both periods there is a fixed unit cost $\bar{c}$ that is reduced according to $a_{t}$, the average productivity of workers employed in the firm in that period.

The model is solved by backward induction. Firstly, the profit function is optimized to get the optimal prices as in the ordinary Salop model. Secondly, the profit function conditional on choosing the optimal price is maximized with respect to the proportion of open-ended contracts in the second period, to obtain the optimal contracting rule. The focus is on the decision on type of labor contract that occurs in the second period. After computing the optimal prices and plugging them into the profit function, it results in:

$$
\Pi=\pi_{1}+\beta \pi_{2}-F
$$

where $\mathrm{F}$ is the entry cost, and first period profits, $\pi_{1}$, are given by:

$$
\pi_{1}=\frac{m d}{n}\left\{\frac{1}{n}+\frac{n}{2 d}\left(E(c)-\bar{c}+a_{1}\right)\right\}^{2}
$$

where $m$ stands for market size as defined above, $d$ denotes product differentiation, $n$ is the number of firms, $E(c)$ represents the expected value of other firms' costs, $\bar{c}$ is a fixed unit cost, and $a_{1}$ denote the average labor productivity in period 1.

Similarly, second period profits, $\pi_{2}$, are given by:

$$
\pi_{2}=\frac{m d}{n}\left\{\frac{1}{n}+\frac{n}{2 d}\left(E(c)-\bar{c}+a_{2}\right)\right\}^{2}-P
$$

where $a_{2}$ denote the average productivity in period 2 and, $P$ represents severance pay which is defined in the next subsection.

Note that profit increases with the difference between the expected value of other firms' costs and firm's unit costs. The extent to which profit reacts to that difference 
depends on the parameters of competition.

The level of competition in this framework is defined according to the value of market size, $m$, product differentiation, $d$, and entry cost, $F$. In particular, an increase in the level of competition occurs if market size, $m$, increases, product differentiation, $d$, decreases or the fixed cost, $F$, is reduced. The number of firms, $n$, is endogenous to the level of competition.

\subsubsection{Labor market}

There are two types of worker-firm matches, high and low productivity matches. Each of them induces a unit cost of $\bar{c}-\alpha_{1}$ or $\bar{c}-\alpha_{2}$, respectively, where $\alpha_{1}>\alpha_{2}$. Actual unit cost is a linear combination of the unit cost induced by each type of worker with weights equal to the proportion of each type of worker in the firm. Each worker's productivity in the firm is unknown a priori. Workers are drawn from a discrete distribution of types such that the employer-employee match has productivity $\alpha_{1}$ with probability $p$ and productivity $\alpha_{2}$ with probability $1-p$.

There are two types of labor contracts, namely, fixed-term and open-ended contracts. In the first period all workers have fixed-term contracts and in the second period, both types of contracts coexist. Workers leave the firm according to the exogenous separation rate $l$ for fixed-term workers and $s$ for open-ended workers, where $l>s$. This assumption captures that open-ended contracted workers are less likely to leave the firm, and hence firms can use open-ended contracts to keep the most productive workers.

When a open-ended worker leaves the firm, the firm has to provide her a severance pay. Let $S$ stand for total severance pay if all workers were hired open-endedly and then replaced. Actual severance pay, $P$, is a proportion of $S$ that depends on the proportion of high productivity matches, $p$, the proportion of high productivity matches which are offered a open-ended contract, $\tau$, and the separation rate for high productivity workers, $s$. In the event of a separation, a new worker is drawn from the same distribution of types as in the first period. 


\subsection{Finding the optimal contract rule}

Which workers will be kept under a fixed-term contract and which ones will be offered an open-ended contract in the second period?. There are two potential optimal strategies for the firm:

1. Selection on high productivity matches: All low productivity workers are kept under fixed-term contracts and the firm decides on the proportion of high productivity workers to offer open-ended contracts.

2. Selection on low productivity matches: All high productivity workers are offered open-ended contracts and the firm decides on the proportion of low productivity workers to keep under open-ended contracts.

Any case between those two would be suboptimal for the firm. Hiring a high productivity worker using a fixed-term contract while hiring a low productivity worker under a open-ended contract implies that expected productivity decreases while expected severance pay stays constant, with respect to the case where the high productivity worker is hired using a open-ended contract and the low productivity worker is hired using a fixed-term contract ${ }^{6}$.

Selection on high productivity matches is more profitable than selection on low productivity matches ${ }^{7}$. In this case, more open-ended contracts imply higher productivity but also higher expected severance pay. This is consistent with the literature on the existence of a causal link between productivity and fixed-term contracts. For the case of Spain, Dolado and Stucchi (2008) find that high conversion rates from fixed-term to openended contracts increase a firm's productivity, while high shares of fixed-term contracts decrease it. Similar conclusions are reached by Boeri and Garibaldi (2007) for Italy and Engellandt and Riphahn (2005) for the Swiss case. Thus, we focus on case 1.

\footnotetext{
${ }^{6}$ Cipollone and Guelfi (2003) show that permanent workers are selected to be the most productive ones. This assumption has been also used in Caggese and Cuñat (2008).

${ }^{7}$ Derivations that lead to conclude that selection on high productivity matches is more profitable than selection on low productivity matches are available from the author upon request.
} 


\subsubsection{Solving the model}

The proportion of high productivity matches employed under open-ended contracts in period $2, \tau$, is our object of interest. Firm productivity and severance pay depend on $\tau$ according to the following expressions:

$$
\begin{gathered}
E\left(a_{2}\right)=p \alpha_{1}+(1-p) \alpha_{2}+p(1-p)(l-s)\left(\alpha_{1}-\alpha_{2}\right) \tau \\
P=p \tau s S
\end{gathered}
$$

Note that both expressions are increasing in $\tau$. More high productivity workers with open-ended contracts induces higher productivity because less high productivity matches will be replaced but it also induces higher total severance pay because more workers will be entitled to severance pay.

Substituting these expressions in the profit function, deriving with respect to $\tau$ and solving for $\tau$, we obtain the value for the optimal proportion of open-ended over total high productivity workers:

$$
\tau=\frac{\left(\frac{1}{2}-p\right)\left(\alpha_{1}-\alpha_{2}\right)+\frac{2 d}{n^{2}}\left(1-\frac{p s S}{\frac{m}{n} p(1-p)(l-s)\left(\alpha_{1}-\alpha_{2}\right)}\right)}{p(1-p)(l-s)\left(\alpha_{1}-\alpha_{2}\right)}
$$

Under perfect competition, $d$ goes to zero and $n$ goes to infinity. Hence, the efficient proportion of open-ended high productivity workers is defined as:

$$
\tau^{e}=\frac{\left(\frac{1}{2}-p\right)}{p(1-p)(l-s)}
$$

Let $A$ denote the ratio between the expected severance pay for a high productivity worker and the relative expected gain in productivity derived from hiring a high productivity worker under a open-ended instead of a fixed-term contract. Analytically, this can be written as: $A=\frac{s S}{\frac{m}{n}(1-p)(l-s)\left(\alpha_{1}-\alpha_{2}\right)}$. Note that, under perfect competition, the equilibrium proportion of open-ended high productivity workers, $\tau$, does not depend on the competition parameters in $A$. However, when the market is not perfectly competitive, $A$ 
bigger than one is associated with values of the proportion of open-ended high productivity workers, $\tau$, that are lower than the efficient value, $\tau^{e}$, and $A$ smaller than one is associated with values of the proportion of open-ended high productivity workers, $\tau$, that are higher than the efficient value, $\tau^{e}$.

How do changes in product market competition affect the proportion of open-ended high productivity workers, $\tau$, when the market is not perfectly competitive?. Comparative statics with endogenous number of firms show that the impact of competition on the proportion of high productivity workers hired under a open-ended contract depends on the value of $A$ according to the following table:

\begin{tabular}{|l|l|l|l|}
\cline { 2 - 4 } \multicolumn{1}{c|}{} & $\frac{d \tau}{d C_{d}}$ & $\frac{d \tau}{d C_{m}}$ & $\frac{d \tau}{d C_{F}}$ \\
\hline$A<\frac{1}{2}$ & - & - & - \\
\hline$\frac{1}{2} \leqslant A<2$ & + & + & - \\
\hline$A \geqslant 2$ & + & + & + \\
\hline
\end{tabular}

where $C_{d}, C_{m}$ and $C_{F}$ represent the different aspects of competition as defined by $d, m$ and $F$, respectively ${ }^{8}$.

To sum up, comparative statics show that product market competition decreases the proportion of high productivity workers with open-ended contracts, $\tau$, if one of the following two conditions is satisfied: (i) $A<\frac{1}{2}$, i.e., severance pay is very low compared to the gain from retaining high quality workers or (ii) $\frac{1}{2} \leqslant A<2$, i.e., severance pay is relatively low, and the increase in competition is driven by a reduction in entry costs. In all other cases, i.e., either if severance pay is very high, or if it is relatively high and the increase in competition is driven by a decrease in product differentiation or an increase in market size, more competition decreases job instability.

Therefore, low values of $A$ imply high values of the proportion of open-ended high productivity workers, $\tau$, and are associated to more competition inducing a reduction in

\footnotetext{
${ }^{8}$ This notation is introduced to ease interpretation. One can assume $C_{d}=-d, C_{m}=m$ and $C_{F}=-F$. And then, $\frac{d \tau}{d C_{d}}, \frac{d \tau}{d C_{m}}$ and $\frac{d \tau}{d C_{F}}$ represent the change in the proportion of open-ended over total high productivity workers as a consequence of a marginal change in competition induced by $d, m$ and $F$, respectively.
} 
the proportion of open-ended high productivity workers, $\tau$. In contrast, high values of $A$ imply low values of the proportion of open-ended high productivity workers, $\tau$, and are associated to more competition inducing an increase in the proportion of open-ended high productivity workers, $\tau$. Intermediate values of $A$ are associated to a more ambiguous prediction. However, note that changes in competition also influence the value of $A$. In particular, $A$ decreases with competition if it is induced by $d$ or $m$, and increases with competition if it is induced by $F$. This implies that $A$ low and high are the only stable values.

\subsection{Implications}

The theoretical framework makes explicit the trade off between productivity and severance pay that firms face when deciding whether to hire workers using fixed-term or openended contracts under heterogeneity in the quality of the employer-employee matches. In particular, all low productivity workers are kept under fixed-term contracts, while the firm decides on which high productivity workers to convert into open-ended. Hence, more open-ended contracts induce more productivity and higher severance pay.

This model not only illustrates the channels through which product market competition may impact the use of labor contracts, it also provides some insights that help to interpret empirical facts. If in estimation, competition is found to reduce the proportion of workers that transition from fixed-term to open-ended contracts, this would be consistent with the case where $A$ is relatively small. In this case, the expected cost of having an open-ended vs. a fixed-term worker is low with respect to the relative expected loss in productivity of hiring a high productivity worker under a fixed-term instead of a open-ended contract. Under this condition, $\tau$ is high relative to the value under perfect competition. On the contrary, the finding that competition induces more open-ended contracts is coherent with the case when $A$ is relatively big, in which the actual $\tau$ is lower than value under perfect competition.

In general, the analysis of how the proportion of fixed-term workers that transition 
to open-ended contracts changes according to the parameters of competition shows that competition is moving the transition rate $\tau$ towards some intermediate efficient value ${ }^{9}$. This is consistent with the general consensus on the existence of some steady-state composition of employment in terms of fixed-term and open-ended employees as argued in Dolado, García-Serrano and Jimeno (2002). Empirical analysis is needed to disentangle which is the situation that applies in practice.

\section{Empirical strategy}

The aim of the empirical analysis is to address the direction and magnitude of the causal relationship between product market competition and job instability. In the main specification, transitions of individuals from fixed-term to open-ended contracts are estimated as a function of variables measuring competition and a set of individual-level controls using data from the Spanish Labor Force Survey. This specification is complemented by another in which the proportion of open-ended contracts in a firm is estimated as a function of variables measuring competition and a set of firm-level controls using the Business Strategies Survey.

\subsection{Individual level analysis of transitions from fixed-term to open-ended contracts}

For the analysis performed at the individual level, the effect of competition on transitions from fixed-term to open-ended contracts is estimated by means of a linear duration model where the equation of interest can be written as follows:

$$
P\left(y_{i j t}=1\right)=\beta_{0}+\beta_{1} C_{j t}+\beta_{2} X_{i j t}+\beta_{3} W_{j t}+\beta_{4} V_{j}+\beta_{5} Z_{t}+\varepsilon_{i j t}
$$

\footnotetext{
${ }^{9}$ In particular, as competition goes to infinity, i.e., market size goes to infinity, unit transportation costs go to zero and entry costs go to zero, and then, the proportion of permanent high productivity workers approaches the value: $\tau^{\text {opt }}=\frac{\left(\frac{1}{2}-p\right)}{p(1-p)(l-s)}$
} 
where $y_{i j t}$ is equal to one if individual $i$ transitions from fixed-term to open-ended contract within sector $j$ at year $t, P()$ represents the probability of the event in brackets happening, and $C_{j t}$ is a measure of competition (see section 3.3 for details). With respect to controls, $X_{i j t}$ includes individual characteristics, namely, age, a married indicator, a household head binary variable, a high-school graduate dummy, a university graduate binary variable, and an Spanish citizenship indicator, number of coworkers, and fixed-term contract duration dummies (in years), $W_{j t}$ stands for the sector-time average difference in wages between open-ended and fixed-term workers, $V_{j}$ represents a set of sector dummies, $Z_{t}$ includes year and quarter dummies. Finally, $\varepsilon_{i j t}$ is the residual.

The dependent variable varies at the individual, sector and time levels, while the measure of competition varies only by sector and time. This could lead to misleading standard errors due to the fact that the identifying variation is lower than the variation existing at the individual level. To avoid this, standard errors are clustered at the sectortime level. Alternatively, two dimensional clustering is applied to address Bertrand, Duflo and Mullainathan (2004)'s concern that standard errors could be underestimated due to serial correlation in the outcome of study.

A shock in the level of product market competition may induce some indirect effects in addition to the direct impact of competition on job instability. In particular, competition may have indirect effects by affecting the composition of the pool of workers in the industry, the degree to which workers switch between sectors and the sector composition of the economy.

Product market competition may induce changes in the composition of the sector's labor force in terms of observable as well as unobservable characteristics, and firms may then decide on the type of labor contract accordingly. In particular, individuals with "good" unobserved characteristics tend to transition to open-ended employment first. Hence, the pool of workers that at each point in time are observed holding a fixed-term contract are the "worse" ones in terms of unobserved characteristics. This implies that stronger shocks to competition would be needed in order to alter their labor contracts and 
thus, ignoring this fact would result in weaker estimates. In order to remove this indirect effect, several individual controls account for changes in workers' observed characteristics. Moreover, individual fixed effects are added in some specifications in order to average out the effect of individual unobserved time invariant traits.

Additionally, changes in product market competition may induce workers to switch across sectors, and sector switching may induce changes in type of labor contract. In particular, sector switching is often associated with a new fixed-term contract. In order to avoid this confounding effect on the results, I consider observations of workers that switch sector as censored at the time of the switch.

Finally, competition may induce some general equilibrium effects that may ultimately have an impact on type of labor contract. Workers may move across sectors as a result of competition shocks and therefore, the relative importance of each sector in the economy may change with the degree of competition. If the sectors that provide less open-ended jobs expand (shrink), this leads to a decrease (increase) in the average transition rate. To prevent this from affecting the results, I weigh each observation using the ratio between the number of workers in the sector one year before the date of the interview and the number of workers in the sector at the time of the interview, in fact keeping the size of each sector unchanged ${ }^{10}$.

\subsection{Firm level analysis of the proportion of open-ended con- tracts}

For the analysis performed at the firm level, the equation of interest is the following:

$$
P_{f j t}=\beta_{0}+\beta_{1} C_{j t}+\beta_{2} X_{f j t}+\beta_{3} V_{j}+\beta_{4} Z_{t}+U_{f}+\varepsilon_{f j t}
$$

where $P_{f j t}$ is the proportion of open-ended over total contracted workers in firm $f$ operating in sector $j$ at year $t$, and $C_{j t}$ stands for a measure of competition. Regarding

\footnotetext{
${ }^{10}$ Theoretically the average of the weights should be close to one. In my sample, it is 0.998 .
} 
controls, $X_{f j t}$ includes a set of firm controls, namely, number of workers, percentage of engineers and college graduates (separating long and short degrees), percentage of part-time open-ended workers, ratio between blue and white collar workers, wages over production, workers training expenditures over production, worker compensations over production, a dummy for merged firm, an indicator for split firm, a binary variable for individual entrepreneur, R\&D over production and percentage of public capital, $V_{j}$ represents sector indicators, $Z_{t}$ stands for year dummies, $U_{f}$ includes firm fixed effects. Finally, $\varepsilon_{f j t}$ is the residual.

Again the measure of competition varies at a higher level of aggregation than the dependent variable, hence estimated standard errors are clustered at the sector-time level.

Product market competition may have an impact on the characteristics of the pool of firms that operate in a sector at each point in time. Hence, together with several firm characteristics, firm fixed effects are added to account for firm-specific time invariant features.

Analogously to the individual level regression, each observation is weighted according to the ratio between the number of workers in the sector one year before the date of the interview and the number of workers in the sector in the year of the interview and consequently, the size of each sector remains constant.

\subsection{Measuring competition}

The measure of competition used in the main specification is the price-cost margin or Lerner Index. This is a standard measure of competition defined as the difference between price and marginal cost as a fraction of price. A higher magnitude of the price-cost margin is associated with lower product market competition.

The price-cost margin was shown by Boone (2000) to perform relatively well as a reflection of the level of product market competition under a variety of theoretical setups. In fact, this measure of competition fits well the theoretical characterization of competition used in this paper. In particular, in the context of the model, the price-cost margin 
is decreasing in market size and increasing in product differentiation and entry costs. Moreover, this measure is found by Boone (2000) to be preferable to most other commonly used measures of competition like the concentration ratio or the inverse of the number of firms.

However, the price-cost margin presents one drawback. It implicitly assumes the existence of constant returns to scale in production. In particular, the measure is biased downward (upward) in the presence of increasing (decreasing) returns to scale. The inclusion of sector dummies in the empirical analysis mitigates the consequences of different levels of returns to scale between sectors since it is unlikely that the sector production technology changes very quickly over time. Additionally, the year dummies would account for the existence of such changes at the economy level. Besides, the equation of interest is estimated using the concentration index as an alternative measure of competition in some specifications and results are consistent with the estimations using the price-cost margin. See Table D.1 in Appendix D.

\subsection{Identification strategies}

One of the main challenges that arise when estimating the impact of product market competition on the use of open-ended contracts is the potential endogeneity of the competition measure. Endogeneity may be present for two reasons. Firstly, the use of open-ended contracts in a sector may influence the entry of other firms, which modifies the level of competition in the sector (this would be endogeneity induced by reverse causality). Secondly, unobserved variables like technology may influence both the use of open-ended contracts and the extent of competition in the sector (in this case, endogeneity would be motivated by omitted variables). To address endogeneity concerns I propose two different strategies, an instrumental variable approach and a quasi-experiment. Both are based on changes in legislation that induce arguably exogenous changes in competition. 


\subsubsection{Instrumental variables: The Regulatory Impact measure}

As argued above, using the price-cost margin as a measure of competition is subject to a potential endogeneity problem. I propose the Regulatory Impact indicator provided by the OECD as an instrument for the price-cost margin.

The Regulatory Impact indicator measures the extent to which anti-competitive legislation in some service sectors (namely, energy, transport, communications, retail distribution, business services and finance), impacts manufacturing sectors. The effect on each manufacturing sector depends on the extent to which it uses the services produced by each service sector. The construction of this index is done in two steps: Firstly, information on barriers to entry, public ownership, vertical integration, market structure and price controls is collected for the energy, transport, communications, retail distribution, business services and finance sectors. Secondly, the information is aggregated at the manufacturing sector level by using the intensity of use of each of those service sectors as weights. The list of the 25 manufacturing sectors for which this information is available is displayed in Table B.1. A more detailed description of this indicator can be found in Conway and Nicoletti (2006). See Tables 1-3 for descriptive statistics on the Regulatory Impact measure.

Analogously to the measures of competition used in the empirical analysis, the Regulatory Impact varies at the sector by time dimension. It changes along time because new anti-competitive laws are promoted in different points in time. It presents variation across sectors because the usage of services is different in each manufacturing sector.

The idea underlying the use of the Regulatory Impact as an instrument for product market competition is that deregulation in the service sectors induces higher competition in the manufacturing sectors. This fact has been documented in Deardorff (2001) and Francois and Wooton (2010), among others ${ }^{11}$. The mechanism behind the positive

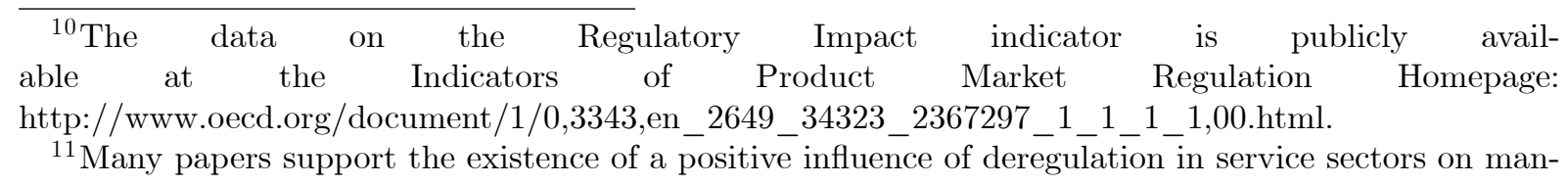


correlation between deregulation in services and competition in manufacturing is that deregulation in the service sectors reduces the prices of services which constitute costs for the manufacturing firms. The decrease in these costs affects each of the final product sectors differently depending on the relative importance of these types of inputs in the production process. This the source of cross-sector variation of the instrument.

The decline in anti-competitive regulation in the above-mentioned service sectors is positively correlated with competition as measured by the price-cost margin in manufacturing sectors ${ }^{12}$. This goes in line the previous argument stated above as well as with previous literature. Still, this may seem contradictory because less regulation in a service sector induces a fall in the price of the services offered by that sector and therefore decreases the manufacturing sectors' costs which will lead to higher price-cost margin, looking like less competition. However, firms adjust prices to changes in costs, and the extent of the adjustment of the price-cost margin to changes in costs would capture precisely the intensity of competition.

Changes in product market regulation in a sector may still be endogenous when explaining the use of the different types of labor contracts within that sector if the government targets both the labor and product markets in one sector simultaneously. In contrast, changes in regulation in a sector are more likely to be exogenous with respect to the use of the different types of labor contracts in other sectors. In this paper, changes in regulation in services are used to study labor contracts in manufacturing sectors.

Additionally, the promotion of new laws regarding the above mentioned service sectors were motivated by a worldwide trend towards economic liberalization of traditionally protected sectors and it is unlikely that the number of fixed-term vs. open-ended contracts

ufacturing sectors. Kerr and Nanda (2007) find evidence that US banking deregulations led to increased competition by inducing entry in sectors throught out the economy. In an application to the automobile industry, Gosh and Morita (2002) show that lower communication costs often reduce the degree of product differentiation leading to more competition. Smith and Thanassoulis (2008) highlight that lower competition in the retail sector induces firms in other sectors to concentrate, reducing the level of competition. Melitz (2003) argues that exposure to trade increases competition in the affected sectors. In practice, the decrease in transport costs after the deregulation of the transport sector has increased exposure to trade in the overall economy.

${ }^{12}$ This is revealed by the first stage regression displayed in Table 5 . 
in the Spanish manufacturing sectors was somehow correlated with the cause of these changes.

Moreover, the intensity of use of services by manufacturing sectors is kept fixed over time at the initial level. Hence, we rule out that endogenous changes in the use of transport, communication, distribution services, etc. by manufacturing sectors may be driving the results.

\subsubsection{Quasi-experiment: The application of EU Directives in Spain}

At the end of the 1990's, the Spanish government, following the indications of the European Union, promoted several laws to liberalize economic activity in sectors such as energy, post, telecommunications, road and rail transport, ports, and tobacco. The aim was to apply structural reforms to promote competition as well as to improve the quality of regulation. In practice, these reforms implied important reductions in the legal barriers to entry in the affected sectors.

The energy sector experienced very important legislative changes in 1997. A new law takes into account EU rules on the electricity single market and lays the foundations for a free market for electric power generation. Additionally, new laws in the gas sector eliminated some regulations concerning distribution at the retail level. Specifically, the percentage of the retail market open to consumer choice goes from 0 to 20 from 1996 to 1997.

The road and rail sector went through an increase in the level of competition from 1997 to 1998. The rail sector continues to be fully owned by public capital. However, the administration is divided into two different entities that compete in the same rail district in the passenger and freight transports markets and that are required to be more profitable because the EU Directive forces the government to reduce subsidies.

The post and telecom sector was subject to changes in competition legislation between 1998 and 1999. In 1997 a law was promoted intending the full liberalization of the telecommunications sector in December 1998. However, it was not until January 1999 
that the new law was enforced. The 1997 EU Directive on the liberalization of the postal services sector translated into the 1998 Spanish Law that liberalized some postal services starting in 1999. The OECD entry regulation indicator shows that the telephone markets became fully competitive in terms of entry regulation starting in 1999 .

The magnitude of the change in competition in these sectors can be approximated by the OECD indicator on barriers to entry ${ }^{13}$. According to this indicator, the barriers to entry decreased by $96.2 \%$ in the energy sector from 1996 to 1997 , by $53.3 \%$ in the rail and road sector from 1997 to 1998 and by $85.9 \%$ in the post and telecom sector from 1998 to 1999. On the other hand, the airlines and retail distribution are reported to experience absolutely no change in their barriers to entry during the period of study. Therefore, they are chosen as control sectors ${ }^{14}$.

Then, the changes in barriers to entry in the energy, rail and road and post and telecom sectors are used as exogenous sources of changes in product market competition. The resulting specification is equivalent to the one described in equation (1) where $C_{j t}$ is a vector that has three components: $C_{j t}^{1}$, a dummy equal to one if an individual is employed in the energy sector in 1997 or after, $C_{j t}^{2}$, an indicator equal to one if the individual is employed in the rail and road sector in 1998 or after and $C_{j t}^{3}$, a binary variable equal to one if the individual is employed in the post and telecom sector in 1999 or after. Positive (negative) coefficients associated to these three variables are interpreted as more competition inducing a higher (lower) probability of transition to an open-ended contract. Additionally, the quasi-experiment specification allows me to control for individual fixed effects $^{15}$.

As argued in section 3.1, the change in competition in the treated sectors indirectly

\footnotetext{
${ }^{13}$ The data on barriers to entry by sector is publicly available at the Indicators of Product Market Regulation Homepage:

http://www.oecd.org/document/1/0,3343,en_2649_34323_2367297_1_1_1_1,00.html

${ }^{14}$ There is no information on barriers to entry for the rest of sectors of the economy. As it is not possible to be sure whether those other sectors belong to the treatment or the control group, they are excluded from the sample.

${ }^{15}$ It is not possible to control for individual fixed effects in the instrumental variables estimation due to lack of variation in the instrument.
} 
affected other sectors in the economy, including the control sectors. Thus, the magnitude of the estimated impact is a lower bound for the total actual impact.

The timing of these reforms was unforeseen. For instance, the OECD Annual Report (2001) asserts that "full liberalization in this sector [telecommunications] came in December 1998, eleven months after the EU target date but in advance of the extended deadline that Spain had negotiated". Additionally, incumbents in some sectors were unaware of the real extent of their application. "In early 1999, the Tribunal assessed substantial fines against the previous public monopoly, Telefónica - 580 million and 750 million Pesetas [8 million euros] - for abuse of dominance in basic and mobile telephony", OECD (2001). Moreover, placebo tests illustrate that the effect of the reforms was not anticipated.

The exogenous nature of this quasi-experiment is originated in the Spanish government's resistance to the application of the EU anti-competitive Directives. The argument used by the Spanish government to oppose the timing imposed by the European Union was that the Spanish economic structure was not ready for this sudden liberalization. However, external political pressures forced the government to promote the corresponding competition-enhancing laws ahead of schedule.

\section{Data and descriptive statistics}

\subsection{Databases}

Given the nature of the empirical question, it is necessary to combine information at the individual or firm level, at which the decisions on type of labor contracts are taken, with information at the sector level, at which product market competition operates.

\section{i) The Spanish Labor Force Survey}

The Spanish Labor Force Survey (Encuesta de la Población Activa) regards to families living in the Spanish territory. The initial sample size is 65000 families by quarter. In practice, this is reduced to 60000 effectively interviewed families that include approxi- 
mately 180000 individuals. The survey provides information on individual labor market status, type of labor contract, duration of labor market status, duration of labor contract, and many other personal and job characteristics (excluding wage). New information is collected on a quarterly frequency. Since 1987, the survey has a rotating panel structure where each family is interviewed a maximum of six consecutive quarters ${ }^{16}$.

To address the lack of information about wages, individuals in the Labor Force Survey are assigned average wages from the Continuous Sample of Working Histories, as described next.

\section{ii) Continuous Sample of Working Histories}

The Continuous Sample of Working Histories (Muestra Continua de Vidas Laborales) includes register data for almost 1.1 million individuals that were in contact with the Social Security Administration at the time the information is collected. For a detailed description of this database see García (2008). In this paper, I use the 2004 wave, which includes individuals who were working, receiving benefits or pensions in 2004. It provides information on the entire working life histories of the selected individuals back to 1967 . Information refers to individual, job and employer characteristics, including wages, which I use to construct average wage by sector, time and type of labor contract. These average wages are then matched to the individuals in the Spanish Labor Force Survey ${ }^{17}$.

\footnotetext{
${ }^{16}$ The panel structure of the data is of key interest for the study of transitions. However the panel version of the survey does not include information on industry of employment at the 2-digits level while the cross-section version does. Therefore, I use the panel data resulting from the match of the cross-sections by means of the algorithm described in Jiménez-Martín and Peracchi (2002). This algorithm matches the cross-sections of the Spanish Labor Force Survey from 1993 to 2003. This matching procedure replicates the panel version of the Spanish Labor Force Survey perfectly and allows researchers to have information on variables that were originally included in the cross-section but not in the panel.

${ }^{17}$ I performed a separate analysis of the transitions from fixed-term to open-ended contracts using the Continuous Sample of Working Histories. Unfortunately, the information on type of labor contract is missing for a large proportion of individuals in the early years of the sample and this reduces the reliability of the estimates. Nevertheless, point estimates are very similar to the ones obtained using the Spanish Labor Force Survey and are available from the author upon request.
} 


\section{iii) Business Strategies Survey}

The Business Strategies Survey (Encuesta sobre Estrategias Empresariales) is an annual survey on a representative sample of Spanish manufacturing firms. The reference population are firms with 10 or more workers operating in the Spanish territory. It has a panel structure that covers the period from 1990 to 2006. In the base year, firms were chosen according to a sampling procedure that assigned weights depending on size. The composition of the sample has been maintained in all the subsequent years. Newly created firms have been added each year with the same sampling criteria as in the base year. Firms are followed even if they split or merge to another firm. The Business Strategies Survey includes information on 4355 firms with an average number of years in the sample of 12 . It provides data on average characteristics of workers in the firm, firm characteristics, accounting data, economic sector and some competition measures.

This dataset allows me to complement the analysis at the individual level with an analysis at the firm level, as well as to compare the results using different measures of competition.

\section{iv) Industrial Enterprise Survey}

The Industrial Enterprise Survey (Encuesta Industrial de Empresas) is available yearly since 1993. It includes information on firms whose main activity has an industrial nature and which are located in the Spanish territory. Its purpose is to collect information on structural and productive characteristics of the manufacturing sectors. The firms included in the sample are representative of the corresponding sector and size cell. It includes information on employment, revenues, costs, investment and other features at the sector level.

The accounting information provided in this survey is used to construct the pricecost margin by sector and year which is used as the main measure of competition in the empirical analysis. 


\section{v) OECD database}

The OECD has developed a wide range of indicators that measure product market regulation by sector. They cover the period 1975-2003 and summarize the status of product market regulation for 36 different sectors in 21 OECD countries. The indicators collect information on several aspects of anti-competitive regulation. As Conway and Nicoletti (2006) state it, "these indicators measure the extent to which policy settings promote or inhibit competition in areas of the product market where competition is viable". In particular, they include information on barriers to entry, public ownership, vertical integration, market structure and price controls as well as the impact of anti-competitive regulation in some service sectors on manufacturing sectors.

This information is used to identify changes in legislation that generate exogenous variation in the level of competition, which is essential for the empirical strategy.

\subsection{Construction of variables}

\section{Transitions}

The analysis focuses on workers' probability of transitioning from a fixed-term to an open-ended contract. The dependent variable is constructed using the Spanish Labor Force Survey and is equal to one if the worker transitions from a fixed-term to an openended contract during a given year and zero if the worker stays with a fixed-term contract. There is no contract identifier hence, it is not known whether two subsequent contracts are held in the same firm or not. For this reason, transitions are defined within sector instead of within firms. Moreover, there appears to be some measurement error because some contracts exceed the maximum legal duration of three years. I treat those observations as censored at the legal limit. This solution was also adopted by Güell and Petrongolo (2007)

\section{Price-cost margin}

The price-cost margin is defined as price over marginal cost divided by price. However, in practice there is no data on marginal costs. The standard solution is to proxy 
the marginal cost using unit cost. In particular, the price-cost margin is computed as production revenue (price by quantity) minus production costs (unit cost by quantity) divided by production revenue. As quantity appears as common factor in the numerator and denominator, this is equivalent to price minus unit cost divided by price. I use the accounting data aggregated by sector and year provided in the Industrial Enterprise Survey to compute this variable.

The price-cost margin has been chosen as the reference measure of competition because it has been shown to perform well under a variety of theoretical settings and moreover, it goes in line with the characterization of competition in the model. However, it is computed by proxying marginal with average costs and it assumes constant returns to scale. Hence, in order to assure that measurement error in the price-cost margin is not driving the results, the concentration index is used as an alternative measure of competition in some specifications with very similar results. See Table D.1 in Appendix D.

\section{Wages}

In Spain, fixed-term contracts are usually associated to lower wages. Hence, when studying the determinants of fixed-term contracts, it is important to control for wage to avoid confounding lower wages and lower job security. Given that the majority of wages are set by collective bargaining, average wages by year, sector and type of labor contract are considered a good proxy of individual wages. In practice, average wages are computed using individual register data from the Continuous Sample of Working Histories ${ }^{18}$.

\footnotetext{
${ }^{18}$ The Continuous Sample of Working Histories does not include actual wages but a top and bottomcoded version of wages. The limits correspond to the minimum and maximum wages subject to taxes each year. I use the algorithm described in Boldrin, Jiménez-Martín and Peracchi (2004) to recover actual wages. The estimation of actual wages relies on the assumption that the true distribution of the logarithm of earnings is a normal distribution where the mean is a linear function of observed individual and job characteristics. When estimating the mean of the logarithm of earnings, I include as regressors age and dummies for male, nationality, sector, fixed-term contract, region and year. The censored values are replaced by the estimated conditional mean of wages.
} 


\subsection{Sample definition and descriptive statistics}

The sample obtained from the Spanish Labor Force Survey includes men aged 16 to 64 . In order to match the yearly frequency of the data on product market competition, I include each individual's first and fifth interviews, i.e., each individual is included at the time when she is first interviewed and in the same quarter of the following year.

For the specification estimating transitions from fixed-term to open-ended employment, I keep only those workers observed having a fixed-term contract at some point in time. As in traditional linear duration models, I consider exits to states different from permanent employment within the sector as censored at the time of exit. Analogously, for the specification estimating transitions to unemployment, I keep only those individuals observed having a job at some point in time and consider as censored exits to states different to unemployment.

Table 1 displays the descriptive statistics for the sample from the Spanish Labor Force Survey used in the instrumental variable estimation. It shows that $7 \%$ of total observations are transitions from fixed-term to open-ended contracts. The average price-cost margin is 0.065 with a standard deviation of 0.028 . The average Regulatory Impact is 0.15 with a standard deviation of 0.04 . Table 2 represents the analogous descriptive statistics for the sample used in the quasi-experiment analysis. It shows that $6.7 \%$ of total observations are transitions from fixed-term to open-ended contracts and that $25 \%$ of total observations are treated.

The sample extracted from the Business Strategies Survey includes all firms whose degree of diversification does not exceed the two-digit level of sector aggregation which represent $91.63 \%$ of the sample. This is done for purely practical reasons in order to be able to assign each firm unequivocally to a single 2-digit sector.

Table 3 displays the descriptive statistics of the sample from the Business Strategies Survey. The average proportion of salaried workers having open-ended contracts in a firm is $78.6 \%$. The average price-cost margin is 0.366 with a standard deviation of 0.059 . The average Regulatory Impact is 0.147 with a standard deviation of 0.021 . 


\section{Empirical results}

The theoretical model shows that there is an efficient value of the transition rate from fixed-term to open-ended contracts and that product market competition will induce more (less) transitions to open-ended contracts if the actual transition rate is lower (higher) than the efficient value. The objective of the empirical exercise is to provide an estimate for the causal impact of product market competition on the use of fixed-term versus open-ended labor contracts. Two different estimation strategies are proposed in order to overcome endogeneity, an instrumental variable strategy and a quasi-experiment. The instrumental variables analysis is performed using individual data from the Spanish Labor Force Survey as well as with firm level data from the Business Strategies Survey, while the quasi-experiment is performed using only individual data from the Spanish Labor Force Survey ${ }^{19}$.

\subsection{Instrumental variables results}

I estimate equation (1), by both OLS and IV using the Regulatory Impact as instrument for the price-cost margin. The dependent variable is equal to one if the individual transitions from a fixed-term to a open-ended contract within a sector in a given year and zero otherwise.

The standard OLS results are displayed in Table 4. The price-cost margin is the variable used to measure the level of product market competition. When included in the regression, the price-cost margin is multiplied by minus one to ease interpretation in terms of competition. Results point at a negative but statistically insignificant relationship between competition and transitions from fixed-term to open-ended employment.

The instrumental variable specification uses the price-cost margin as measure of competition and the Regulatory Impact indicator as instrument. The first stage (Table 5)

\footnotetext{
${ }^{19}$ The quasi-experiment is not performed using the Business Strategies Survey because the sectors affected in the quasi-experiment are not covered by the Business Strategies Survey.
} 
reflects a positive correlation between liberalization in the service sectors and competition in the industries making use of those services ${ }^{20}$. Table 6 displays the second stage results.

Comparison of Table 4 and Table 6 evidences the necessity of accounting for endogeneity in this set up. OLS induced a positive bias in the coefficient that one can interpret according to the two potential sources of endogeneity. Firstly, industries where transitions from fixed-term to open-ended employment often occur may be targeted by potential entrants that plan to compete by using cheaper labor contracts. Secondly, the introduction of technology that standardizes the production process may induce less transitions to open-ended employment because that technology reduces differences in productivity between workers as well as less competition because the necessary investment in technology acts as a barrier to entry of new firms.

Comparing the columns in Table 6 , one finds that the sequential introduction of time and sector dummies highly modifies the coefficient towards more negative values. This gives us some intuition on the importance of accounting for common time trends as well as time invariant industry characteristics in this context. The application of weights such that changes in sector size are taken into account has only a small impact on the magnitude of the coefficient. If anything, the estimation using weights reflects a slightly weaker negative impact. This happens because the industries where the identifying variation occurs expand ${ }^{21}$.

The coefficient from the most complete specification including time dummies, sector dummies and weights (column 4) indicates that a one standard deviation increase in the level of product market competition decreases the probability of becoming open-ended for a fixed-term worker by more than $30 \%{ }^{22}$.

\footnotetext{
${ }^{20}$ All regressions fulfill the criterium that the F-statistic of the excluded instruments is bigger than the corresponding Stock and Yogo critical value so the instrument is not weak.

${ }^{21}$ This is coherent with the results obtained in the previous literature that shows that more competition induces higher employment.

${ }^{22}$ The standard deviation of the price-cost margin is 0.028 . Multiplied by the coefficient, -0.757 , this gives the average absolute change in the proportion of open-ended workers, which is -0.021 . This is equivalent to a decrease of $30.286 \%$ in the average probability of transition.

This is a lower bound for the true effect because one expects that the estimated effect becomes stronger once individual fixed effects are included. This occurs because the omission of individual time invariant
} 
The coefficients associated to the individual controls on the equation for the probability of transitioning from fixed-term to open-ended contracts are shown in Appendix B. They are fairly standard, and consistent with previous studies using logit estimates (see Alba, 1998) as well as competing risks duration models (see Güell and Petrongolo, 2007). Likewise Güell and Petrongolo (2007), results show two pronounced spikes at one and three years duration, coinciding with the legal limit for fixed-term contracts.

I find that the level of product market competition increases the proportion of fixedterm contracts that are not converted into open-ended ones within a sector. This is the closest one can set to a "pure" competition effect. However, competition may have an indirect impact on type of labor contract by inducing some individuals to move between sectors. As moving to a new sector is usually associated with a new fixed-term contract, this effect can be attributed to the change in competition in the sector of origin. I thus estimate an additional specification in which each individual is assigned to the sector where they are initially hired under a fixed-term contract, irrespective of whether they later switch sector or not. This allows to shed some light on the relative importance of the direct effect with respect to the indirect effect through sector switching. A dummy for switchers and an interaction of switcher and the competition measure are added to the original specification. I find that the impact of competition is not statistically different between the group of switchers and non-switchers. If anything, the impact of competition is stronger in the group of switchers. As mentioned earlier, switching sectors reduces the probability of getting an open-ended contract in the period immediately after the switch. Consistently, results show that getting a open-ended contract after a fixed-term contract is lower for switchers. See Table D.2 in Appendix D.

In the estimation performed using the Business Strategies Survey, the OLS results displayed in the first panel of Table 7 point at a negative impact of competition on the

unobserved characteristics in the group of controls biases the coefficients for the other controls towards zero. Some evidence on this fact is discussed in section 5.2. Note that it is not possible to include individual fixed effects in the instrumental variable specification because the instrument weakens significantly once individual fixed effects are included. 
proportion of fixed-term contracts. When comparing those results with those from the instrumental variable estimation (second panel), one observes that the OLS results induce a bias towards zero. In OLS and IV estimations, the magnitude of the effect becomes stronger when time and sector dummies are included but it becomes slightly weaker when weights are applied. Therefore, the sign of the coefficient and the direction of the different biases are coherent with the specification using the Labor Force Survey. When firm fixed effects are included (column 5), the estimated impact gets weaker although it is still negative and very significant ${ }^{23}$. Table C.2 displays the estimated coefficients for the control variables.

The coefficient for the most complete estimation including time dummies, sector dummies, weights and firm fixed effects (column 5) indicates that a one standard deviation increase in the level of product market competition decreases the proportion of open-ended workers in the firm by more than $18 \%^{24}$.

\subsection{Quasi-experiment results}

The results obtained by making use of the application of competition-enhancing EU Directives as a quasi-experiment are displayed in Table 8. The estimated coefficients for the impact of a rise in competition motivated by a decrease in legal barriers to entry on the probability of transitioning from fixed-term to open-ended employment are consistent across the three different treated sectors as well as with the instrumental variable specification. A stronger negative impact appears after the introduction of time and sector dummies while weighting the observations does not change the estimated coefficients significantly.

\footnotetext{
${ }^{23}$ The most complete specification (column 5) is the only one for which the instrument is not weak according to the Stock and Yogo test. In this case, the first stage is showing a positive correlation between the price-cost margin and the Regulatory Impact. This is coherent with the results obtained with individual data.

${ }^{24}$ The standard deviation of the price-cost margin is 0.059. Multiplied by the coefficient, -2.464 , this gives the average absolute change in the proportion of permanent workers, which is -0.145 . This is equivalent to a decrease of $18.45 \%$ in the average proportion of permanent workers.
} 
As expected, the estimation including individual fixed effects increases the magnitude of the coefficients substantially. This happens because individuals with "very bad" unobserved characteristics would not become open-ended even if the level of competition was very low. Moreover, individuals with "very good" unobserved characteristics would not stay under a fixed-term contract even if the level of competition was very high. Hence, controlling for individual time-invariant characteristics results in a stronger estimate for the negative impact of product market competition on the probability of the transition from fixed-term to open-ended employment. This suggests that the final coefficient obtained in the instrumental variables specification is a lower bound of the true effect.

In order to interpret the magnitude of the results, I also estimate an equation in which the competition measure is the interaction of a dummy for working in a treated sector in the post-treatment period with the proportion of removed legal barriers to entry in each sector according to the $\mathrm{OECD}^{25}$. This leads to a coefficient of -0.12 , which indicates that the elimination of legal barriers to entry (the change from legal monopoly to free entry) induced a decrease of $12 \%$ in the probability of becoming open-ended for workers hired under fixed-term contracts. See Table D.3 in Appendix D.

Bertrand et al. (2004) state that difference-in-differences standard errors could be understated due to serial correlation in the outcome of study. In order to address that concern, I use, in addition to standard cluster mentioned above, two dimensional cluster where one dimension is sector-time cells and the other one is the individual. This takes into account the correlation of errors within individuals over time as well as the correlation within sector-time cells which is the level of aggregation of the competition measures. Results show that there is essentially no change in the level of significance of the estimates. See Table D.4 in Appendix D.

As Imbens (2004) suggests, in the context of the difference-in-differences approach it is essential to provide some support for the validity of two assumptions: (i) overlap

\footnotetext{
${ }^{25}$ According to the OECD, barriers to entry decrease by $96 \%$ in the energy sector from 1996 to 1997, by $86 \%$ in the post and telecom sector from 1998 to 1999 and by $53 \%$ in the rail and road sector from 1997 to 1998.
} 
in the covariate distributions and (ii) exogeneity or unconfoundedness assumptions. To address (i), Table 2 shows that the distribution of the covariates for workers employed in the treated sectors and the distribution of the covariates for workers employed in the untreated sectors present significant overlap. With respect to (ii), Figure 3 presents some evidence that the pre-treatment trend was quite similar between treated and untreated sectors. Additionally, I estimate the treatment effect on a pre-treatment variable. In particular, the regressions address the impact of the treatment on transitions from fixedterm to open-ended contract a year before the treatment actually took place. The results of this placebo test are displayed in Table 11. The "placebo" effect is not significant on average.

Finally, the number of degrees of freedom in the quasi-experimental regressions is 39 (or 44 when individual fixed-effects are excluded). This could raise some concerns about whether the number of clusters is small to provide reliable estimates. To address these concerns, I perform bootstrap over clusters and show the coefficients arising from each iteration in Figure 4. The coefficients arising from each interation are found to be consistently negative and their magnitudes are very similar. This assures that no particular clusters of observations are leading the results.

\subsection{Sector switching results}

Analogously to Goldberg et al. (1999), I use sector switching as an additional measure of job instability. The baseline specification can be written as in equation (1). The outcome of interest, $y_{i j t}$, equals one if individual $i$ in sector $j$ at time $t$ switches sector of employment and zero otherwise. The vector $X_{i j t}$ contains the set of individual characteristics listed in section 3.1 where fixed-term contract duration dummies are substituted by job duration dummies in years and an indicator for fixed-term contract is added. Moreover, $W_{i j t}$ represents now the sector-year average wages in place of the difference in average wage between open-ended and fixed-term contracts.

Three complementary sector assignment methods provide evidence on how competition 
affects the probability of sector switching. First, each individual is assigned to the sector where he is initially employed even if he switches sector. This allows to draw a conclusion regarding how changes in competition in one sector induces workers to move to other sectors. Second, individuals are assigned to the sector where they are finally employed even if they move sector. Following this estimation, one deduces how the probability of moving from other sectors to a particular sector changes according to competition in the receiving sector. Third, workers are assigned to the sector where they are actually employed in each period. Using this sector assignment method, one can infer how sector switching is affected by differences in the level of competition between sectors.

Results are displayed in Table 9. They show that when the level of competition increases in one sector, it is less likely that workers in that sector transition to other sectors and it is more probable that workers in other sectors move to that sector. Additionally, workers switch sectors to a greater extent when the differences in competition between sectors widen. In particular, a one percentage point increase in the level of competition in a sector reduces the probability that the average worker in that sector moves to a different sector by over $22 \%^{26}$, while it increases the probability that a worker in a different sector moves to that sector by over $36 \%^{27}$. Additionally, a one percentage point rise in the difference in competition between two sectors increases the probability that a worker switches sector by over $12 \%^{28}$. In general, one expects that an upturn (reduction) in the level of competition in a sector provokes an inflow (outflow) of workers into (from) that sector.

\footnotetext{
${ }^{26}$ The standard deviation of the price-cost margin is 0.039 . Multiplied by the coefficient, -0.075 , this gives the average absolute change in the proportion of switchers, which is -0.003 . This is equivalent to a decrease of $22.307 \%$ in the average probability of sector switching.

${ }^{27}$ The standard deviation of the price-cost margin is 0.039 . Multiplied by the coefficient, 0.124, this gives the average absolute change in the proportion of switchers, which is 0.005 . This is equivalent to a decrease of $36.875 \%$ in the average probability of sector switching.

${ }^{28}$ The standard deviation of the price-cost margin is 0.039 . Multiplied by the coefficient, 0.125 , this gives the average absolute change in the proportion of switchers, which is 0.002 . This is equivalent to a decrease of $12.536 \%$ in the average probability of sector switching.
} 


\subsection{Unemployment results}

The probability that a worker becomes unemployed constitutes another dimension of job instability. It is also very related to the type of labor contract because fixed-term contracts are associated with a higher probability of job separation. However, keeping a worker under a fixed-term contract and discarding the worker could potentially be substitute strategies for the firm. Therefore, the impact of product market competition on unemployment is unknown a priori. The specification of interest is very similar to the one described by equation (1) where the outcome of interest, $y_{i j t}$, is now equal to one if individual $i$ working in sector $j$ at time $t$ becomes unemployed in a given year. The set of individual characteristics, $X_{i j t}$, includes, in addition to the controls in equation (1), a dummy for fixed-term contract and, in substitution of fixed-term contract duration dummies, job duration dummies in years. $W_{j t}$ stands for sector-year average wages (instead of the difference in average wage between open-ended and fixed-term labor contracts) and it is included in order to proxy the opportunity cost of keeping the worker.

The results obtained from the instrumental variable specification are shown in table $10^{29}$. More product market competition induces a rise in the probability of becoming unemployed. An increase in competition by one standard deviation provokes a rise in the probability of becoming unemployed over $56 \%{ }^{30}$.

This conclusion is in line with the theoretical model proposed by Amable and Gatti (2004) in which an increase in product market competition boosts the separation rate.

\footnotetext{
${ }^{29}$ When estimating the probability of job separation, there is no specification using the weights because job separation is one channel through which the sector composition of the economy changes. Hence, we are already addressing sector composition changes explicitly.

${ }^{30}$ The standard deviation of the price-cost margin is 0.039 . Multiplied by the coefficient, -0.181 , this gives the average absolute change in the proportion of unemployed, which is 0.007 . This is equivalent to an increase of $55.818 \%$ in the average probability of job separation.
} 


\section{Conclusion}

There is a very active literature on the impact of product market competition on labor market outcomes. This paper contributes to this literature by estimating the impact of competition on job instability as measured by the probability of holding an open-ended contract.

I propose a theoretical model that is, to the best of my knowledge, the first one to shed light on the relationship between competition and type of labor contract. In the context of the model, competition is characterized by market size, product differentiation and entry cost. Open-ended contracts differ from fixed-term contracts in the probability of separation and the dismissal cost. The model has a number of predictions that are consistent with the data: (i) Fixed-term and open-ended contracts coexist in all sectors, (ii) Open-ended workers are more productive than fixed-term workers, and (iii) Product market competition alters the degree of use of fixed-term and open-ended contracts. In particular, the model indicates that when the transition rate to open-ended contracts is low (high), more competition induces a rise (decrease) in the proportion of fixed-term contracts.

The empirical analysis focuses on Spain, which is the country with the highest incidence of fixed-term contracts in Europe. Employment relationships in Spain traditionally start under fixed-term contracts and hence, the majority of the individuals in the Spanish labor market are subject to this type of contract at some point in their working lifes. Combining data from the Spanish Labor Force Survey, the Continuous Sample of Work-

ing Histories, the Business Strategies Survey and the Industrial Enterprise Survey, job instability is shown to rise with competition. The result is robust to the use of different estimation strategies, databases, and measures of competition.

The empirical strategy makes use of changes in legislation as a source of exogenous variation in the level of product market competition in order to overcome endogeneity concerns. Exogeneity originates in (i) The impact of deregulation in service sectors on manufacturing sectors, and (ii) The enforcement of the EU Directives enhancing compe- 
tition in Spain.

Overall, the results show that product market competition has a significant impact on job instability. In particular, one standard deviation increase in product market competition as measured by the price-cost margin induces a fall in the probability of a worker transitioning from a fixed-term to a open-ended contract in a given year over $30 \%$, a reduction in the probability that the average worker in that sector moves to a different sector by over $-22 \%$, an upturn in the probability that a worker in a different sector moves to that sector by over $36 \%$, and an increase in the probability of a worker becoming unemployed of over $56 \%$. The estimated impact of competition on the type of labor contract is likely a lower bound on the true total effect. This happens because competition can also lead to changes in the type of labor contract for individuals who are induced to switch sector. As switching induces a lower probability of transitioning to a open-ended contract, the total effect would be higher.

Thus, the evidence is consistent with a direct contemporaneous causal effect of product market competition on job instability. However, the long run effects of changes in competition may be different from the ones found for the short run. For instance, if higher job instability induced by increases in competition allows firms to better screen the most productive workers, those may enjoy more stable positions in the long run. This question is left for future research. 


\section{References}

[1] Alba-Ramírez, Alfonso 1998. How temporary is temporary employment in Spain. Journal of Labor Research 19, Number 4, 695-710.

[2] Amable, Bruno and Donatella Gatti 2004. Product market competition, job security, and aggregate employment. Oxford Economic Papers 56(4): 667-686.

[3] Bassanini, Andrea \& Giorgio Brunello 2010. Barriers to entry, deregulation and workplace training: A theoretical model with evidence from europe. CESifo Working Paper Series 2945, CESifo Group Munich.

[4] Bertrand, Marianne 2004. From the invisible handshake to the invisible hand? How import competition changes the employment relationship. Journal of Labor Economics 22(4): 723 .

[5] Bertrand, Marianne, Esther Duflo and Sendhil Mullainathan 2004. How much should we trust differences-in-differences estimates?. The Quarterly Journal of Economics 119(1): 249-275.

[6] Bertrand, Marianne and Francis Kramarz 2002. Does entry regulation hinder job creation? Evidence from the French retail industry. Quarterly Journal of Economics117(4): 1369-1413.

[7] Blanchard, Olivier and Francesco Giavazzi 2003. Macroeconomic effects of regulations and deregulation in goods and labor markets. Quarterly Journal of Economics 118(3): 879-907.

[8] Blanchard, Olivier and Augustin Landier 2002. The perverse effects of partial labour market reform: Fixed-term contracts in France. The Economic Journal 112(480): F214-F244.

[9] Boldrin, Michele., Sergi. Jiménez-Martín and Franco. Peracchi 2004. Micro-modelling of retirement behaviour in Spain. in Social security and retirement around the world: 
Micro-estimation, ed. by J. Gruber, and D. Wise: Chicago University Press for the NBER.

[10] Boeri, Tito and Pietro. Garibaldi 2007. Two tier reforms of empoyment protection: A honeymoon effect?. The Economic Journal 117: F357-F385.

[11] Boone, Jan 2000. Measuring product market competition. CEPR Working Paper 2636.

[12] Bover, Olympia and Ramón Gómez 2004. Another look at unemployment duration: Exit to a permanent vs. a temporary job. Investigaciones Economicas 28(2): 285-314, May.

[13] Caggese, Andrea and Vicente Cuñat, 2008. Financing constraints and fixed-term employment contracts. The Economic Journal 118(533): 2013-2046.

[14] Cipollone, Piero and Anita Guelfi 2003. Tax credit policy and firms' behaviour: The case of subsidy to open-end labour contract in Italy. Economic Working Paper n.471, Bank of Italy, Economic Research Department.

[15] Conway, Paul and Giuseppe Nicoletti 2006. Product market regulation in the nonmanufacturing sectors of OECD Countries: Measurement and highlights. OECD Economics Department Working Papers 530, OECD Publishing.

[16] Cuñat, Vicente and Maria Guadalupe 2006. Globalization and the provision of incentives inside the firm. Journal of Labor Economics 27, no. 2: 179-212.

[17] De la Rica, Sara and Amaia Iza 2005. Career planning in Spain: Do fixed-term contracts delay marriage and parenthood?. Review of the Economics of the Household 3: $49-73$.

[18] Deardorff, Alan V. 2001. International provision of trade services, trade, and fragmentation. Review of International Economics, 9(2): 233-48. 
[19] Dolado, Juan José. and Rodolfo Stucchi 2008. Do fixed-term contracts affect TFP? Evidence from Spanish manufacturing firms. IZA Discussion Papers 3832, Institute for the Study of Labor (IZA).

[20] Dolado, Juan José, Carlos Garcia-Serrano and Juan Francisco Jimeno 2002. Drawing lessons from the boom of fixed-term jobs in Spain. The Economic Journal 112(480): F270-F295.

[21] Ebell, Monique and Christian Haefke 2009. Product market deregulation and the U.S. employment miracle. Review of Economic Dynamics 12(3): 479-504.

[22] Engellandt, Axel, and Regina T. Riphahn 2005. Temporary contracts and employee effort. Labour Economics 12(3): 281-299.

[23] Fiori, Giuseppe, Giuseppe Nicoletti, Stefano Scarpetta and Fabio Schiantarelli 2007. Employment outcomes and the interaction between product and labor market deregulation: Are they substitutes or complements? Boston College Working Papers in Economics 663, Boston College Department of Economics, revised 08 Aug 2008.

[24] Francois, Joseph F. and Ian Wooton 2010. Market structure and market access. The World Economy 33(7): 873-893, 07.

[25] García, José I. 2008. La muestra continua de vidas laborales. Una guía de uso para el análisis de transiciones. Revista de Economía Aplicada E-1 (vol. XVI): 5-28.

[26] Goldberg, Linda S., Joseph Tracy and Stephanie Aaronson 1999. Exchange rates and employment instability: Evidence from matched CPS data. The American Economic Review 89(2), Papers and Proceedings of the One Hundred Eleventh Annual Meeting of the American Economic Association (May, 1999): 204-210.

[27] Griffith, Rachel, Rupert Harrison and Gareth Macartney, 2007. Product market reforms, labour market institutions and unemployment. The Economic Journal 117(519): C142-C166, 03. 
[28] Griffith, Rachel 2001. Product market competition, efficiency, and agency costs: An empirical analysis. Institute for Fiscal Studies Working Paper W01/12.

[29] Guadalupe, María 2007. Product market competition, returns to skill, and wage inequality. Journal of Labor Economics 25: 439-474.

[30] Güell, Maia and Barbara Petrongolo 2007. How binding are legal limits? Transitions from fixed-term to open-ended work in Spain. Labour Economics 14 (2): 153-183.

[31] Heyman, Fredrik, Helena Svaleryd. and Jonas Vlachos 2008. Competition, takeovers and gender discrimination. CEPR Discussion Paper No DP6879.

[32] Imbens, Guido W. 2004. Nonparametric estimation of average treatment effects under exogeneity: A review. The Review of Economics and Statistics 86: 4-29.

[33] Jiménez-Martín, Sergi and Franco Peracchi 2002. Sample attrition and labor force dynamics. Evidence from the Spanish labor force survey. Spanish Economic Review 4(2): 79-102.

[34] Levine, Ross, Alexey Levkov and Yona Rubinstein 2008. Racial discrimination and competition. NBER Working Paper No W14273 (July 20, 2009).

[35] Nicoletti, Giuseppe and Stefano Scarpetta 2005. Product market reforms and employment in OECD countries. OECD Economics Department Working Papers 472, OECD, Publishing.

[36] OECD/CLP 2001. Annual Report on Competition policy developments in Spain, 2000 to OECD Committee on Competition Law and Policy, Paris.

[37] Raith, Michael 2003. Competition, risk and managerial incentives. American Economic Review 93: 1425-1436.

[38] Stock, James H. and Motohiro Yogo 2005. Testing for weak instruments in linear IV regression. In D.W.K. Andrews and J.H. Stock, eds. Identification and inference for 
econometric models: Essays in honor of Thomas Rothenberg. Cambridge: Cambridge University Press, 2005: 80-108. 


\section{Figures}

\section{Figure 1: Proportion of fixed-term contracts over time in Spain}



This graph plots average proportion of fixed-term over total number of labor contracts by year in Spain. Data is drawn from the Eurostat. The data is publicly available at the Eurostat Statistics website: http://epp.eurostat.ec.europa.eu/portal/page/portal/statistics/search_database. The period included is 1987-2009. 


\section{Figure 2: Proportion of fixed-term contracts over time by indus-}

\section{try in Spain}
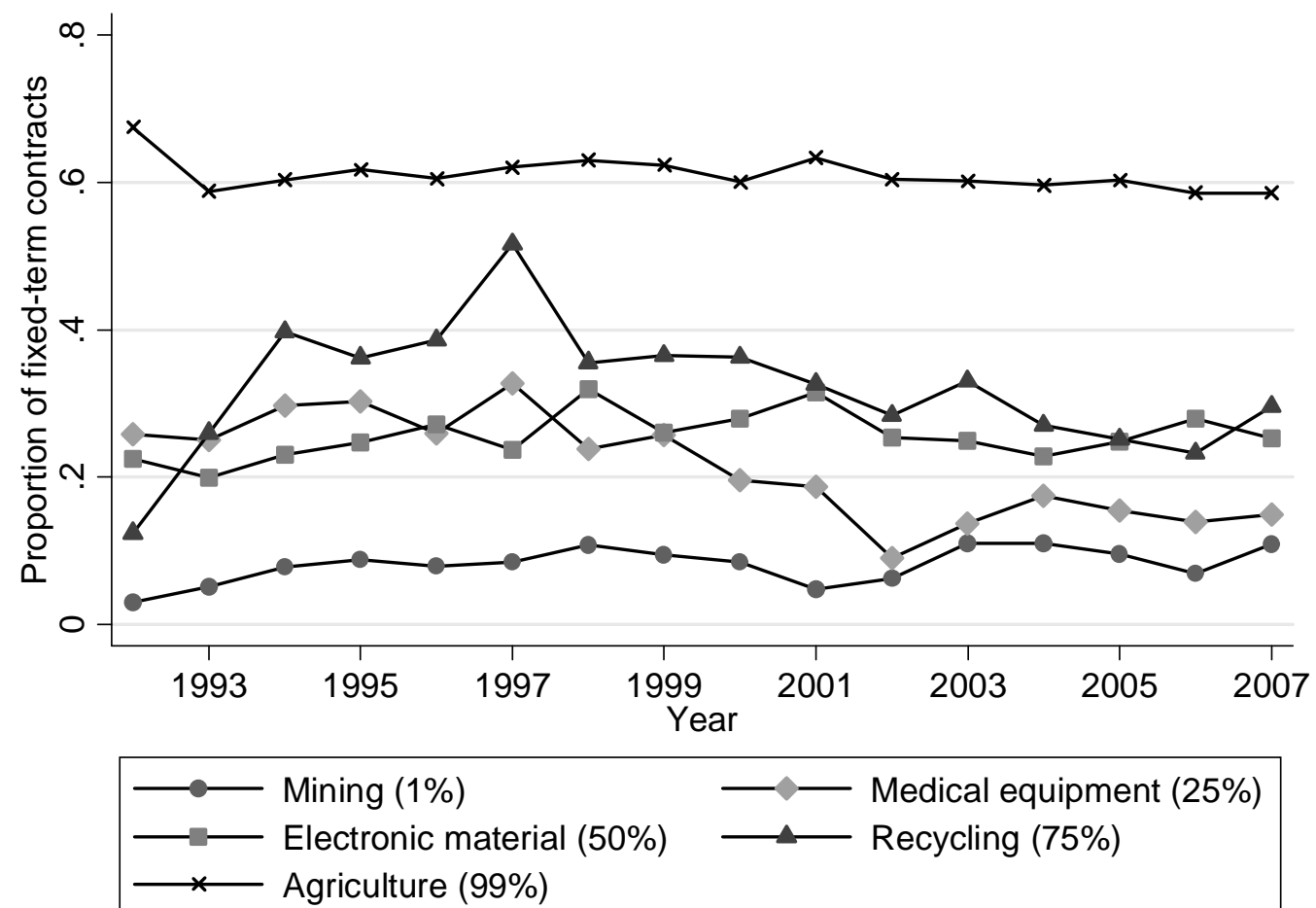

This graph displays the evolution of the average proportion of fixed-term contracts over time in five sectors. These five sectors represent the key percentiles of the distribution of average proportion of fixed-term contracts by sector. Data is drawn from the Spanish Labor Force Survey. The sample includes contracted workers in the mining, medical equipment, electronic material, recycling and agriculture sectors from 1992 to 2007. 
Figure 3: Time trends in the proportion of fixed-term over total employment for the treated and untreated sectors in the quasiexperiment using the Spanish Labor Force Survey

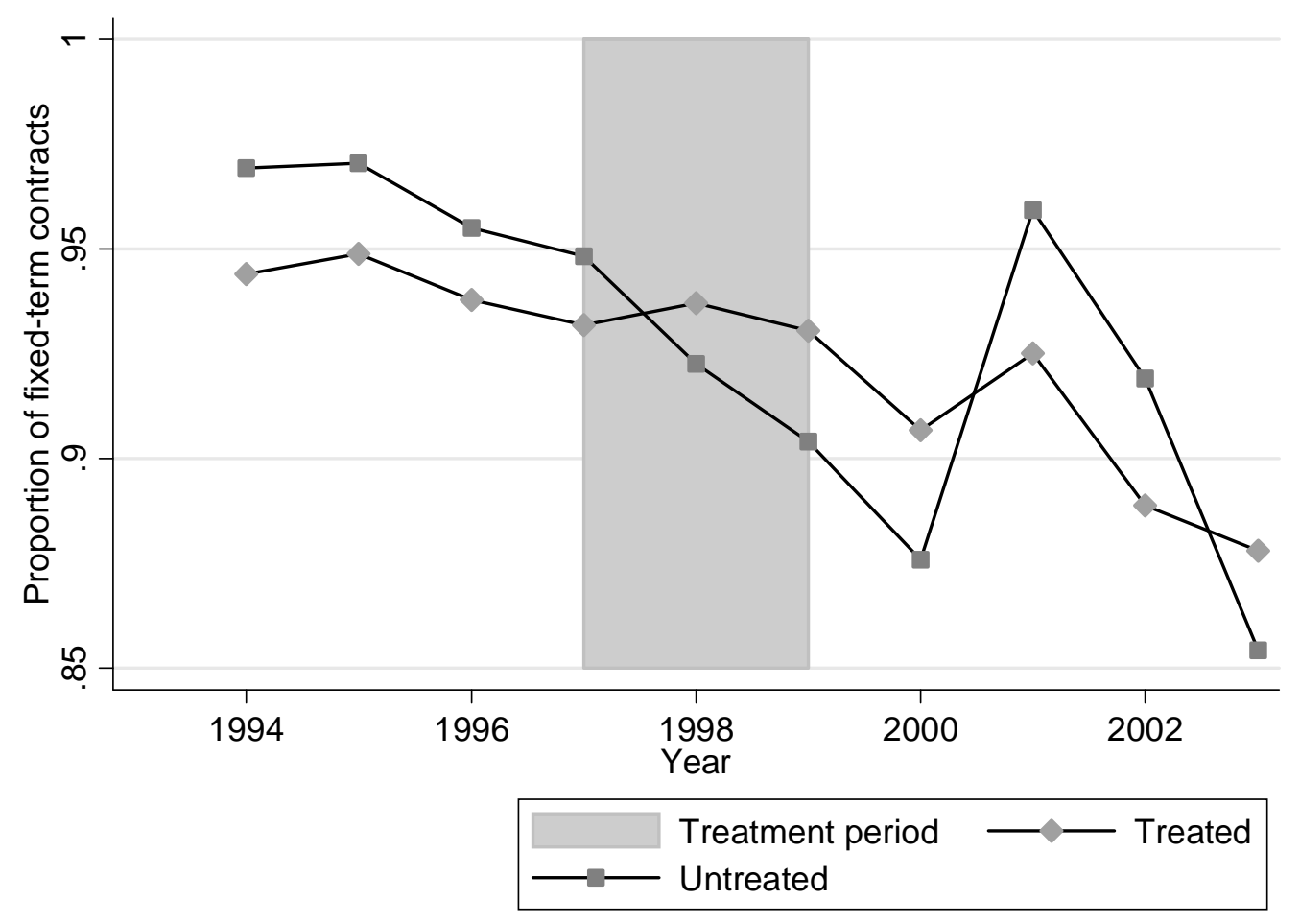

This graph displays the time trends for the average proportion of fixed-term over total number of labor contracts in the treated and the untreated sectors in the quasi-experiment estimation using the Spanish Labor Force Survey. The treated sectors are energy, rail\&road and post\&telecom and the untreated sectors are airlines and retail distribution. Data is drawn from the Spanish Labor Force Survey. The sample includes men aged 16 to 64 with a fixed-term contract, who have no seasonal jobs (the same sample that is used in the quasi-experiment estimation). 


\title{
Figure 4: Bootstrap estimated coefficients for the quasi-experiment
}

\author{
using the Spanish Labor Force Survey
}

Bootstrap coefficients

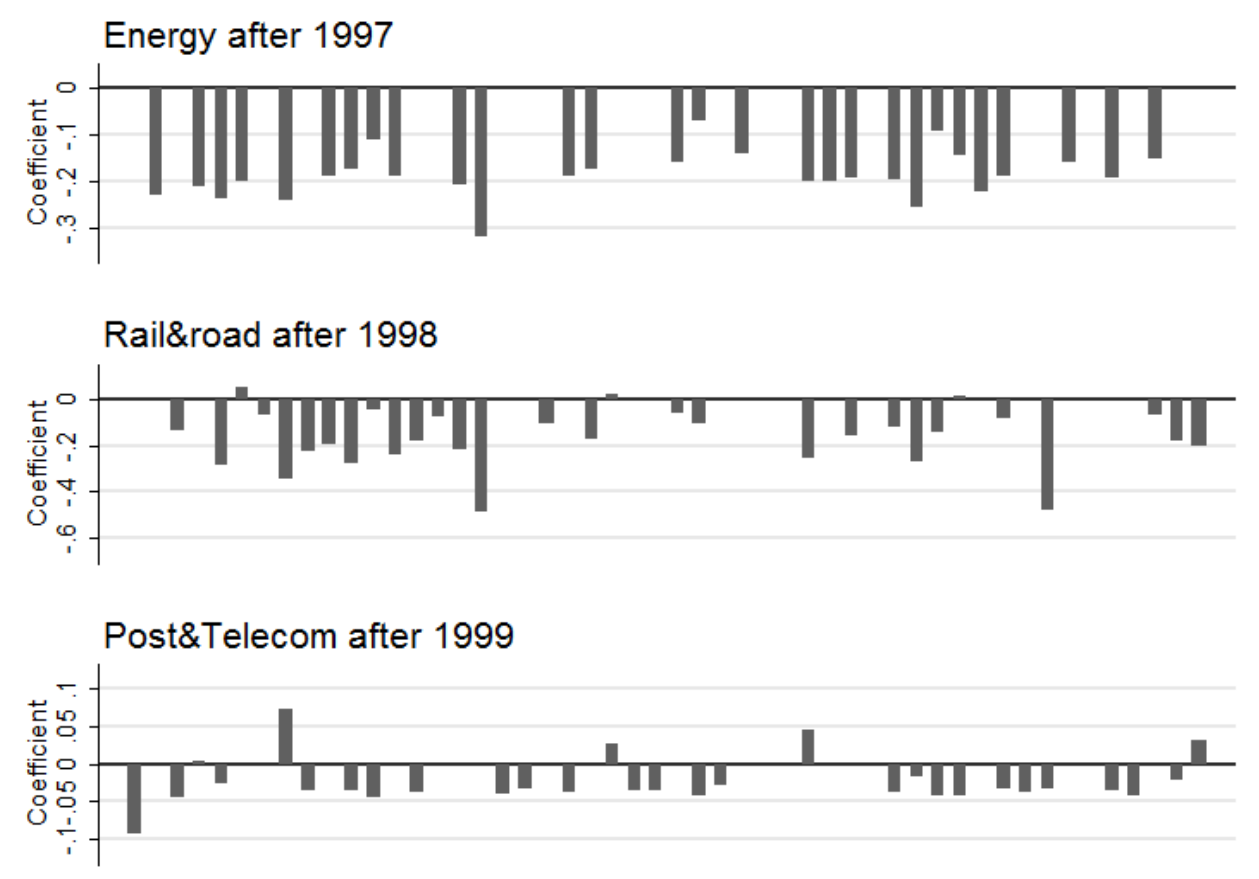

This graph represents the estimated coefficients resulting from 50 random draws from the sample of clusters in the quasi-experiment estimation. The dependent variable is equal to one if the individual transitions from fixed-term to open-ended employment within a sector in a given year, and zero otherwise. The measures of competition are a dummy for working in the energy sector in 1997 or after, a dummy for working in the rail\&road sector in 1998 or after and a dummy for working in the post\&telecom sector in 1999 or after. The coefficients are marked with * if the level of significance is between $5 \%$ and $10 \%,{ }^{* *}$ if the level of significance is between $1 \%$ and $5 \%$ and ${ }^{* * *}$ if the level of significance is less than $1 \%$. The regression includes controls for individual and job characteristics (age, married, household head, dummies for region of residence, high-school graduate, university graduate, number of coworkers, dummies for duration of the fixed-term contract in years and quarter dummies), year and industry of employment dummies, as well as individual fixed-effects. Individuals are weighted according to the ratio between the number of workers in their industry one year before the date of the interview and the number of workers in their industry at the time of the interview. The sample is drawn from the Spanish Labor Force Survey and includes men aged 16 to 64 with a fixed-term contract who have no seasonal jobs over the period 1993 to 2003. The industries included are energy, rail\&road, post\&telecom, airline and retail. The airline and retail industries serve as controls. Errors are clustered by sector-year. 


\section{Tables}

Table 1: Descriptive statistics for the instrumental variables estimation (Labor Force Survey)

\begin{tabular}{lllll} 
& Mean & Sd & Min & Max \\
\cline { 2 - 5 } & 0.07 & 0.256 & 0 & 1 \\
\hline \hline Transition to open-ended contract & -0.065 & 0.028 & -0.269 & 0.045 \\
- Price-cost margin & -0.15 & 0.04 & -0.546 & -0.099 \\
- Regulatory Impact & 29.079 & 9.588 & 16 & 64 \\
Age & 0.339 & 0.473 & 0 & 1 \\
Married & 0.24 & 0.427 & 0 & 1 \\
Household head & 0.708 & 0.455 & 0 & 1 \\
High school grad & 0.073 & 0.26 & 0 & 1 \\
University grad & 0.991 & 0.092 & 0 & 1 \\
Spanish citizen & 54.335 & 35.606 & 1 & 100 \\
Number of coworkers & 0.32 & 0.467 & 0 & 1 \\
One year fixed-term contract duration & 0.082 & 0.274 & 0 & 1 \\
Two years fixed-term contract duration & & 0.165 & 0 & 1 \\
Three years fixed-term contract duration & 0.028 & 17146.58 & 112.164 & 129953.3 \\
Open-ended vs. fixed-term wage difference & 46764.89 & & 1 & 52 \\
Region & & & 1 & 4 \\
Quarter & & & 1993 & 2003 \\
Year & & & 25 \\
Sector & & & 0 & 1 \\
\hline & & & 0 & 1 \\
\hline
\end{tabular}

The sample is drawn from the Spanish Labor Force Survey and includes men aged 16 to 64 with a fixed-term contract who have no seasonal jobs. It comprises the period from 1993 to 2003. The industries included are listed in table B.1. Sample size is 31737. 


\section{Table 2: Descriptive statistics for the quasi-experiment (Labor}

\section{Force Survey)}

\begin{tabular}{lllllll} 
& \multicolumn{2}{c}{ Full sample } & \multicolumn{2}{c}{ Treated sectors } & \multicolumn{2}{c}{ Control sectors } \\
\cline { 2 - 7 } & Mean & Sd & Mean & Sd & Mean & Sd \\
\hline \hline Transition to open-ended contract & 0.067 & 0.25 & 0.072 & 0.259 & 0.063 & 0.242 \\
Energy after 1997 & 0.023 & 0.15 & 0.051 & 0.219 & 0 & 0 \\
Rail\&road after 1998 & 0.174 & 0.379 & 0.381 & 0.486 & 0 & 0 \\
Post\&telecom after 1999 & 0.053 & 0.223 & 0.115 & 0.319 & 0 & 0 \\
Age & 29.612 & 9.47 & 33.045 & 9.834 & 26.709 & 8.085 \\
Married & 0.35 & 0.477 & 0.501 & 0.5 & 0.223 & 0.416 \\
Household head & 0.329 & 0.47 & 0.473 & 0.499 & 0.206 & 0.405 \\
High school grad & 0.725 & 0.447 & 0.663 & 0.473 & 0.777 & 0.416 \\
University grad & 0.064 & 0.246 & 0.061 & 0.24 & 0.067 & 0.25 \\
Spanish citizen & 0.99 & 0.099 & 0.988 & 0.108 & 0.992 & 0.09 \\
Number of coworkers & 40.352 & 36.855 & 44.006 & 34.557 & 37.261 & 38.426 \\
One year fixed-term contract duration & 0.291 & 0.454 & 0.308 & 0.462 & 0.277 & 0.447 \\
Two years fixed-term contract duration & 0.089 & 0.284 & 0.094 & 0.291 & 0.085 & 0.278 \\
Three years fixed-term contract duration & 0.025 & 0.157 & 0.03 & 0.172 & 0.021 & 0.143 \\
Open-ended vs. fixed-term wage difference & 49800.34 & 24010.26 & 60302.18 & 28809.37 & 40916.8 & 13781.89 \\
\hline
\end{tabular}

There are 9667 observations in total, 4430 in the treated sectors and 5237 in the untreated sectors. The sample is drawn from the Spanish Labor Force Survey and includes men aged 16 to 64 with a fixed-term contract who have no seasonal jobs over the period 1993 to 2003. The industries included are energy, rail\&road, post\&telecom, airline and retail. The airline and retail industries serve as controls. 
Table 3: Descriptive statistics for the instrumental variables estimation (Business Strategies Survey)

\begin{tabular}{lllll} 
& Mean & Sd & Min & Max \\
\hline \hline Proportion of open-ended workers & 0.786 & 0.247 & 0 & 1 \\
- Price cost margin & -0.366 & 0.059 & -0.504 & -0.179 \\
- Regulatory Impact & -0.147 & 0.021 & -0.2 & -0.099 \\
Number of workers & 225.885 & 546.304 & 1 & 14390 \\
Percentage of university grads (long degree) & 3.82 & 6.358 & 0 & 88 \\
Percentage of university grads (short degree) & 5.096 & 7.945 & 0 & 100 \\
Percentage of part-time workers & 1.602 & 6.75 & 0 & 100 \\
Blue over white collar workers & 0.37 & 2.823 & 0 & 216 \\
Wages over production & 0.287 & 0.239 & 0.013 & 12.569 \\
Training expenditures per worker & 17.593 & 100.917 & 0 & 3838.965 \\
Worker compensations over production & 0.287 & 0.239 & 0.013 & 12.569 \\
Merged firm & 0.016 & 0.126 & 0 & 1 \\
Split firm & 0.011 & 0.103 & 0 & 1 \\
Individual entrepreneur & 0.393 & 0.488 & 0 & 1 \\
R\&D over production & 0.007 & 0.023 & 0 & 0.637 \\
Public capital over total capital & 1.588 & 11.463 & 0 & 100 \\
Year & & & 1992 & 2003 \\
Sector & & & 1 & 19 \\
\hline
\end{tabular}

The number of observations is 18370. The sample is drawn from the Business Strategies Survey and includes firms whose level of diversification does not exceed one industry as defined by the 2-digit classification over the period 1992 to 2006. The industries included are listed in table C.1. 


\section{Table 4: Estimation by ordinary least squares (Labor Force Sur-}

\begin{tabular}{lcccc} 
vey) & & & & \\
& basic & year & sector & weighted \\
\cline { 2 - 5 } Dep var: Transition to open-ended & $(1)$ & $(2)$ & $(3)$ & $(4)$ \\
\hline - Price-cost margin & -.054 & 0.001 & -.036 & -.033 \\
& $(0.067)$ & $(0.054)$ & $(0.125)$ & $(0.127)$ \\
Number of observations & 31043 & 31043 & 31043 & 31043 \\
$R^{2}$ & 0.141 & 0.148 & 0.149 & 0.149 \\
\hline \hline
\end{tabular}

The dependent variable is equal to one if the individual transitions from a fixed-term to open-ended employment within a sector in a given year, and zero otherwise. The measure of competition is the price-cost margin multiplied by minus one. The coefficients are marked with * if the level of significance is between $5 \%$ and $10 \%, * *$ if the level of significance is between $1 \%$ and $5 \%$ and *** if the level of significance is less than $1 \%$. The basic regression includes controls on individual and job characteristics (age, married, household head, dummies for region of residence, high-school graduate, university graduate, number of coworkers, dummies for duration of the fixed-term contract in years and quarter dummies) . The second column adds year dummies to the basic regression. The third column includes, in addition to the variables in column 2, dummies for industry of employment. Finally, column 4 displays the results when individuals are weighted according to the ratio between the number of workers in their industry one year before the date of the interview and the number of workers in their industry at the time of the interview. The sample is drawn from the Spanish Labor Force Survey and includes men aged 16 to 64 with a fixed-term contract who have no seasonal jobs over the period 1993 to 2003 . The industries included are listed in table B.1. The price-cost margin is obtained from the Industrial Enterprise Survey. Errors are clustered by sector-year. 


\section{Table 5: First stage (Labor Force Survey)}

\begin{tabular}{lcccc} 
& basic & year & sector & weighted \\
\cline { 2 - 5 } Dep var: - Price-cost margin & $(1)$ & $(2)$ & $(3)$ & $(4)$ \\
\hline - Regulatory Impact & 0.362 & 0.45 & 0.265 & 0.268 \\
& $(0.054)^{* * *}$ & $(0.063)^{* * *}$ & $(0.055)^{* * *}$ & $(0.055)^{* * *}$ \\
Number of observations & 31043 & 31043 & 31043 & 31043 \\
$R^{2}$ & 0.349 & 0.459 & 0.872 & 0.871 \\
F-statistic of excluded instruments & 45.362 & 52.368 & 23.296 & 24.047 \\
\hline \hline
\end{tabular}

The dependent variable is minus the price-cost margin. The instrument for which the coefficient is displayed is minus the Regulatory Impact Indicator. The coefficients are marked with * if the level of significance is between $5 \%$ and $10 \%,{ }^{* *}$ if the level of significance is between $1 \%$ and $5 \%$ and $* * *$ if the level of significance is less than $1 \%$. The basic regression includes controls on individual and job characteristics (age, married, household head, dummies for region of residence, high-school graduate, university graduate, number of coworkers, dummies for duration of the fixed-term contract in years and quarter dummies). The second column adds year dummies to the basic regression. The third column includes, in addition to the variables in column 2, dummies for industry of employment. Finally, column 4 displays the results when individuals are weighted according to the ratio between the number of workers in their industry one year before the date of the interview and the number of workers in their industry at the time of the interview. The sample is drawn from the Spanish Labor Force Survey and includes men aged 16 to 64 with a fixed-term contract who have no seasonal jobs over the period 1993 to 2003. The price-cost margin is obtained from the Industrial Enterprise Survey. The Regulatory Impact Indicator is drawn from the OECD database. The industries included are listed in table B.1. Errors are clustered by sector-year. The F-statistics of the excluded instrument are bigger than the critical values provided by Stock and Yogo (2005) which indicates that the instrument is not weak. 


\section{Table 6: Estimation by instrumental variables (Labor Force Sur-}

\begin{tabular}{lcccc} 
vey) & & & & \\
& basic & year & sector & weighted \\
\cline { 2 - 5 } Dep var: Transition to open-ended & $(1)$ & $(2)$ & $(3)$ & $(4)$ \\
\hline - Price-cost margin & 0.658 & 0.093 & -.802 & -.771 \\
& $(0.171)^{* * *}$ & $(0.069)$ & $(0.341)^{* *}$ & $(0.335)^{* *}$ \\
Number of observations & 31043 & 31043 & 31043 & 31043 \\
$R^{2}$ & 0.135 & 0.148 & 0.148 & 0.148 \\
\hline \hline
\end{tabular}

The dependent variable is equal to one if the individual transitions from fixed-term to open-ended employment within a sector in a given year, and zero otherwise. The measure of competition is the pricecost margin multiplied by minus one. This is instrumented using the Regulatory Impact. The coefficients are marked with $*$ if the level of significance is between $5 \%$ and $10 \%, * *$ if the level of significance is between $1 \%$ and $5 \%$ and $* * *$ if the level of significance is less than $1 \%$. The basic regression includes controls on individual and job characteristics (age, married, household head, dummies for region of residence, high-school graduate, university graduate, number of coworkers, dummies for duration of the fixed-term contract in years and quarter dummies). The second column adds year dummies to the basic regression. The third column includes, in addition to the variables in column 2, dummies for industry of employment. Finally, column 4 displays the results when individuals are weighted according to the ratio between the number of workers in their industry one year before the date of the interview and the number of workers in their industry at the time of the interview. The sample is drawn from the Spanish Labor Force Survey and includes men aged 16 to 64 with a fixed-term contract who have no seasonal jobs over the period 1993 to 2003. The price-cost margin is obtained from the Industrial Enterprise Survey. The Regulatory Impact is drawn from the OECD database. The industries included are listed in table B.1. Errors are clustered by sector-year. 


\title{
Table 7: Business Strategies Survey results
}

\author{
Estimation by Ordinary Least Squares
}

\begin{tabular}{lccccc} 
& basic & year & sector & weights & firm fe \\
\cline { 2 - 6 } Dep var: Proportion of open-ended & $(1)$ & $(2)$ & $(3)$ & $(4)$ & $(5)$ \\
\hline - Price-cost margin & -0.205 & -0.252 & -0.377 & -0.371 & -0.366 \\
& $(0.062)^{* * *}$ & $(0.058)^{* * *}$ & $(0.118)^{* * *}$ & $(0.119)^{* * *}$ & $(0.104)^{* * *}$ \\
Number of observations & 17705 & 17705 & 17705 & 17705 & 17705 \\
\hline \hline
\end{tabular}

Estimation by Instrumental Variables

\begin{tabular}{lccccc} 
& basic & year & sector & weights & firm fe \\
\cline { 2 - 6 } Dep var: Proportion of open-ended & $(1)$ & $(2)$ & $(3)$ & $(4)$ & $(5)$ \\
\hline - Price-cost margin & 3.623 & 1.322 & -5.098 & -5.999 & -2.464 \\
& $(17.341)$ & $(0.881)$ & $(3.567)$ & $(4.884)$ & $(1.199)^{* *}$ \\
Number of observations & 17705 & 17705 & 17705 & 17705 & 17417 \\
\hline \hline
\end{tabular}

The dependent variable is the proportion of open-ended over total contracted workers. The measure of competition is average price-cost margin in the industry multiplied by minus one. This is instrumented using the Regulatory Impact. The coefficients are marked with * if the level of significance is between $5 \%$ and $10 \%, * *$ if the level of significance is between $1 \%$ and $5 \%$ and $* * *$ if the level of significance is less than $1 \%$. The basic regression includes controls on workers and firm characteristics (number of workers, percentage of engineers and college graduates -separating long and short degrees-, percentage of workers with intermediate education, percentage of part-time permanent workers, ratio of blue over white collar workers, wages over production, workers training expenditures over production, worker compensations over production, merged firm, split firm, individual entrepreneur, R\&D over production and percentage of public capital). The second column adds year dummies to the basic regression. The third column includes, in addition to the variables in column 2, dummies for industry of employment. Column 4 displays the results when firms are weighted according to the ratio between the number of workers in their industry one year before the date of the interview and the number of workers in their industry at the time of the interview. Finally, column 5 is estimated including firm fixed-effects. The sample is drawn from the Business Strategies Survey and comprises firms whose level of diversification does not exceed one industry as defined by the 2-digit classification over the period 1992 to 2006. The industries included are listed in table C.1. The price-cost margin is obtained from the Business Strategies Survey. The Regulatory Impact is drawn from the OECD database. Errors are clustered by sector-year. The F statistic of the excluded instrument in the first stage corresponding to the last column estimation is 25.38. This figure is well over the critial value provided by Stock and Yogo (2005) which indicates that the instrument is not weak. 


\section{Table 8: Quasi-experiment (Labor Force Survey)}

\begin{tabular}{lccccc} 
& basic & year & sector & weighted & ind fe \\
\cline { 2 - 6 } Dep var: Transition to open-ended & $(1)$ & $(2)$ & $(3)$ & $(4)$ & $(5)$ \\
\hline Energy after 1997 & 0.02 & -.026 & -.046 & -.050 & -.197 \\
& $(0.017)$ & $(0.014)^{*}$ & $(0.026)^{*}$ & $(0.026)^{* *}$ & $(0.029)^{* * *}$ \\
Rail\&road after 1998 & 0.015 & -.010 & -.022 & -.021 & -.040 \\
& $(0.012)$ & $(0.01)$ & $(0.009)^{* *}$ & $(0.009)^{* *}$ & $(0.007)^{* * *}$ \\
Post\&telecom after 1999 & 0.032 & -.026 & -.021 & -.025 & -.127 \\
& $(0.02)$ & $(0.019)$ & $(0.023)$ & $(0.022)$ & $(0.067)^{*}$ \\
Number of observations & 9623 & 9623 & 9623 & 9623 & 7191 \\
$R^{2}$ & 0.163 & 0.169 & 0.169 & 0.169 & 0.255 \\
\hline \hline
\end{tabular}

The dependent variable is equal to one if the individual transitions from fixed-term to open-ended employment within a sector in a given year, and zero otherwise. The measures of competition are a dummy for working in the energy sector in 1997 or after, a dummy for working in the rail\&road sector in 1998 or after and, a dummy for working in the post\&telecom sector in 1999 or after. The coefficients are marked with * if the level of significance is between $5 \%$ and $10 \%, * *$ if the level of significance is between $1 \%$ and $5 \%$ and $* * *$ if the level of significance is less than $1 \%$. The basic regression includes controls on individual and job characteristics (age, married, household head, dummies for region of residence, high-school graduate, university graduate, number of coworkers, dummies for duration of the fixed-term contract in years and quarter dummies). The second column adds year dummies to the basic regression. The third column includes, in addition to the variables in column 2, dummies for industry of employment. Column 4 displays the results when individuals are weighted according to the ratio between the number of workers in their industry one year before the date of the interview and the number of workers in their industry at the time of the interview. Finally, column 5 adds individual fixed-effects. The sample is drawn from the Spanish Labor Force Survey and comprises men aged 16 to 64 with a fixed-term contract who have no seasonal jobs over the period 1993 to 2003. The industries included are energy, rail\&road, post\&telecom, airline and retail. The airline and retail industries serve as controls. Errors are clustered by sector-year. 


\section{Table 9: Probability of switching industry (Labor Force Survey)}

\section{Initial sector}

\begin{tabular}{lccc} 
& basic & year & sector \\
\cline { 2 - 4 } Dep var: Sector switching & $(1)$ & $(2)$ & $(3)$ \\
\hline - Price-cost margin & 0.061 & 0.03 & -.075 \\
& $(0.016)^{* * *}$ & $(0.012)^{* *}$ & $(0.048)$ \\
Number of observations & 85364 & 85364 & 85364 \\
$R^{2}$ & 0.031 & 0.033 & 0.034 \\
\hline
\end{tabular}

Final sector

\begin{tabular}{lccc} 
& basic & year & sector \\
\cline { 2 - 4 } Dep var: Sector switching & $(1)$ & $(2)$ & $(3)$ \\
\hline - Price-cost margin & 0.058 & 0.03 & 0.124 \\
& $(0.014)^{* * *}$ & $(0.013)^{* *}$ & $(0.06)^{* *}$ \\
Number of observations & 85364 & 85364 & 85364 \\
$R^{2}$ & 0.031 & 0.033 & 0.034 \\
\hline \hline
\end{tabular}

\begin{tabular}{lccc} 
Actual sector & basic & year & sector \\
\cline { 2 - 4 } Dep var: Sector switching & $(1)$ & $(2)$ & $(3)$ \\
\hline - Price-cost margin & 0.057 & 0.03 & 0.125 \\
& $(0.014)^{* * *}$ & $(0.013)^{* *}$ & $(0.061)^{* *}$ \\
Number of observations & 85364 & 85364 & 85364 \\
$R^{2}$ & 0.031 & 0.033 & 0.034 \\
\hline \hline
\end{tabular}

The dependent variable is equal to one if the individual switches industry in a given year, and zero otherwise. The measure of competition is the price-cost margin multiplied by minus one. This is instrumented using the Regulatory Impact. The coefficients are marked with * if the level of significance is between $5 \%$ and $10 \%,{ }^{* *}$ if the level of significance is between $1 \%$ and $5 \%$ and $* * *$ if the level of significance is less than $1 \%$. The first panel displays the results for the estimation where individuals are assigned to their initial industry of employment irrespective of whether they switch sector or not. The second panel shows the estimations arising when individuals are assigned to their final sector of employment irrespective of whether they switch sector or not. And, the third panel, presents the results for the estimation in which individuals are assigned to their actual industry of employment. The basic regression 
includes controls on individual and job characteristics (age, married, household head, dummies for region of residence, high-school graduate, university graduate, number of coworkers, dummies for duration of the job, an indicator for having a fixed-term contract, average wage by sector-year and quarter dummies) The second column adds year dummies to the basic regression. Finally, the third column includes, in addition to the variables in column 2, dummies for industry of employment. The sample is drawn from the Spanish Labor Force Survey and includes men aged 16 to 64 with a non seasonal job over the period 1993 to 2003. The price-cost margin is obtained from the Industrial Enterprise Survey. The Regulatory Impact is drawn from the OECD database. The industries included are listed in table B.1. Errors are clustered by sector-year. The $\mathrm{F}$ test of the excluded instrument in the first stage corresponding to the last column estimations are 31.03, 31.45 and 31.33 respectively. These figures are clearly over the critical values provided by Stock and Yogo (2005) which indicates that the instrument is not weak. 


\section{Table 10: Probability of becoming unemployed (Labor Force Sur-}

vey)

Estimation by ordinary least squares

\begin{tabular}{lccc} 
& basic & year & sector \\
\cline { 2 - 4 } Dep var: Transitions to unemployment & $(1)$ & $(2)$ & $(3)$ \\
\hline - Price-cost margin & -.012 & 0.001 & 0.102 \\
& $(0.011)$ & $(0.009)$ & $(0.028)^{* * *}$ \\
Number of observations & 86447 & 86447 & 86447 \\
$R^{2}$ & 0.121 & 0.124 & 0.124 \\
\hline \hline
\end{tabular}

Estimation by instrumental variables

\begin{tabular}{lccc} 
& basic & year & sector \\
\cline { 2 - 4 } Dep var: Transitions to unemployment & $(1)$ & $(2)$ & $(3)$ \\
\hline - Price-cost margin & -.073 & -.005 & 0.181 \\
& $(0.017)^{* * *}$ & $(0.013)$ & $(0.066)^{* * *}$ \\
Number of observations & 86447 & 86447 & 86447 \\
$R^{2}$ & 0.121 & 0.124 & 0.124 \\
\hline \hline
\end{tabular}

The dependent variable is equal to one if the individual becomes unemployed in a given year, and zero otherwise. The measure of competition is the price-cost margin multiplied by minus one. This is instrumented using the Regulatory Impact. The coefficients are marked with * if the level of significance is between $5 \%$ and $10 \%,{ }^{* *}$ if the level of significance is between $1 \%$ and $5 \%$ and ${ }^{* * *}$ if the level of significance is less than $1 \%$. The basic regression includes controls on individual and job characteristics (age, married, household head, dummies for region of residence, high-school graduate, university graduate, number of coworkers, dummies for duration of the job, an indicator for having a fixed-term contract, average wage by sector-year and quarter dummies) The second column adds year dummies to the basic regression. Finally, the third column includes, in addition to the variables in column 2, dummies for industry of employment. The sample is drawn from the Spanish Labor Force Survey and includes men aged 16 to 64 with a non-seasonal job over the period 1993 to 2003. The price-cost margin is obtained from the Industrial Enterprise Survey. The Regulatory Impact drawn from the OECD database. The industries included are listed in table B.1. Errors are clustered by sector-year. The F statistic of the excluded instrument in the first stage corresponding to the last column estimation is 31.56. This figure is clearly over the critical value provided by Stock and Yogo (2005) which indicates that the instrument is not weak. 


\section{Table 11: Placebo quasi-experiment (Labor Force Survey)}

\begin{tabular}{lccccc} 
& basic & year & sector & weighted & ind fe \\
\cline { 2 - 6 } Dep var: Transition to open-ended & $(1)$ & $(2)$ & $(3)$ & $(4)$ & $(5)$ \\
\hline Energy after 1996 & 0.021 & -.015 & -.042 & -.043 & -.016 \\
& $(0.016)$ & $(0.013)$ & $(0.022)^{*}$ & $(0.022)^{*}$ & $(0.022)$ \\
Rail\&road after 1997 & 0.014 & -.004 & -.013 & -.013 & 0.072 \\
& $(0.011)$ & $(0.009)$ & $(0.008)$ & $(0.008)$ & $(0.015)^{* * *}$ \\
Post\&telecom after 1998 & 0.037 & -.012 & -.004 & -.005 & -.024 \\
& $(0.018)^{* *}$ & $(0.018)$ & $(0.018)$ & $(0.018)$ & $(0.024)$ \\
Number of observations & 9623 & 9623 & 9623 & 9623 & 7191 \\
$R^{2}$ & 0.164 & 0.169 & 0.169 & 0.169 & 0.254 \\
\hline \hline
\end{tabular}

The dependent variable is equal to one if the individual transitions from fixed-term to open-ended employment in a given year, and zero otherwise. The measures of competition are dummies for working in a treated sector one year before the treatment actually takes place or later. That is, a dummy for working in the energy sector in 1996 or after, a dummy for working in the rail\&road sector in 1997 or after and, a dummy for working in the post\&telecom sector in 1998 or after. The coefficients are marked with * if the level of significance is between $5 \%$ and $10 \%$, ** if the level of significance is between $1 \%$ and $5 \%$ and $* * *$ if the level of significance is less than $1 \%$. The basic regression includes controls on individual and job characteristics (age, married, household head, dummies for region of residence, high-school graduate, university graduate, number of coworkers, dummies for duration of the fixed-term contract in years and quarter dummies). The second column adds to the basic regression dummies for year. The third column includes, in addition to the variables in column 2, dummies for industry of employment. Column 4 displays the results when individuals are weighted according to the ratio between the number of workers in their industry one year before the date of the interview and the number of workers in their industry at the time of the interview. Finally, column 5 adds individual fixed-effects. The sample is drawn from the Spanish Labor Force Survey and comprises men aged 16 to 64 with a fixed-term contract who have no seasonal jobs over the period 1993 to 2003. The industries are energy, rail\&road, post\&telecom, airline and retail. The airline and retail industries serve as controls. Errors are clustered by sector-year. 


\section{Appendix A: The theoretical model}

\section{Solving the model}

This section is devoted to show some intermediate derivations of the results of the theoretical model developed in section 2.

Each firm maximizes expected profits with respect to the proportion of open-ended out of high productivity workers, $\tau$. The formula for the expected profits is:

$$
\begin{aligned}
E(\Pi) & =E\left(\pi_{1}\right)+\beta E\left(\pi_{2}\right)= \\
& =E\left(\pi_{1}\right)+\beta\left[\begin{array}{c}
\frac{m d}{n}\left\{\frac{1}{n}+\frac{n}{2 d}(E(c)-\bar{c})\right\}^{2}+\left\{\frac{m}{n}+\frac{m n}{2 d}(E(c)-\bar{c})\right\} E\left(a_{2}\right) \\
+\frac{m n}{4 d} E\left(a_{2}^{2}\right)-p \tau s S
\end{array}\right]
\end{aligned}
$$

where $\tau$ is implicitly included in the expressions for $E\left(a_{2}\right)$ and $E\left(a_{2}^{2}\right)$ which are:

$$
\begin{aligned}
& E\left(a_{2}\right)=p \alpha_{1}+(1-p) \alpha_{2}+p(1-p)(l-s)\left(\alpha_{1}-\alpha_{2}\right) \tau \\
& E\left(a_{2}^{2}\right)=p \alpha_{1}^{2}+(1-p) \alpha_{2}^{2}+p(1-p)(l-s)\left(\alpha_{1}^{2}-\alpha_{2}^{2}\right) \tau
\end{aligned}
$$

Maximizing expected profits with respect to $\tau$, one obtains the following first order condition:

$$
\left\{\frac{m}{n}+\frac{m n}{2 d}(E(c)-\bar{c})\right\}\left[-p(1-p)(l-s)\left(\alpha_{1}-\alpha_{2}\right)\right]+\frac{m n}{4 d}\left[-p(1-p)(l-s)\left(\alpha_{1}^{2}-\alpha_{2}^{2}\right)\right]+p s S=0
$$

where:

$$
E(c)-\bar{c}=-E\left(a_{2}\right)=-p \alpha_{1}-(1-p) \alpha_{2}-p(1-p)(l-s)\left(\alpha_{1}-\alpha_{2}\right) \tau
$$

Solving for $\tau$, we get the expression for the optimal proportion of fixed-term out of high productivity workers:

$$
\tau^{*}=\frac{\frac{2 d}{n^{2}}+\left(\frac{1}{2}-p\right)\left(\alpha_{1}-\alpha_{2}\right)-\frac{2 d}{m n} \frac{p s S}{p(1-p)(l-s)\left(\alpha_{1}-\alpha_{2}\right)}}{p(1-p)(l-s)\left(\alpha_{1}-\alpha_{2}\right)}
$$




\section{Comparative statics}

The comparative statics analysis assumes that the number of firms is endogenous. In order to know how the optimal proportion of open-ended over total high productivity workers changes according to the level of product differentiation, $d$, one needs to expand the following expression:

$$
\frac{d \tau^{*}}{d d}=\frac{\partial \tau^{*}}{\partial d}+\frac{\partial \tau^{*}}{\partial n} \frac{\partial n}{\partial d}=\frac{\partial \tau^{*}}{\partial d}+\frac{\partial \tau^{*}}{\partial n}\left(-\frac{\frac{\partial \Pi}{\partial d}}{\frac{\partial \Pi}{\partial n}}\right)
$$

where the first equality holds because of the chain rule of derivation and the second holds because of the implicit function theorem and the fact that $\Pi=0$ due to free entry.

Computing the relevant derivatives and substituting their value on the previous expression, one reaches the following conclusion:

$$
\operatorname{sign}\left(\frac{d \tau^{*}}{d d}\right)=\operatorname{sign}\left(\frac{m}{n}-2 \frac{p s S}{p(1-p)(l-s)\left(\alpha_{1}-\alpha_{2}\right)}\right)
$$

This implies that an increase in competition through a decrease in product differentiation would decrease the proportion of open-ended workers if and only if the expression above is positive and the reverse is true.

The same reasoning as for the incidence of changes in product differentiation, $d$, applies for the incidence of market size, $m$, on $\tau$. One finds that the sign of the total derivative is the opposite for both parameters. That is,

$$
\operatorname{sign}\left(\frac{d \tau^{*}}{d m}\right)=\operatorname{sign}\left(2 \frac{p s S}{p(1-p)(l-s)\left(\alpha_{1}-\alpha_{2}\right)}-\frac{m}{n}\right)
$$

This shows that an increase in competition through a rise in market size would reduce the proportion of open-ended workers if and only if the above expression is negative and the reverse is true. Note that when the expression above is positive expression (3) is negative and vice versa.

Finally, the expression for the total change in the optimal proportion of open-ended 
over total high productivity workers caused by changes in entry costs is:

$$
\frac{d \tau^{*}}{d F}=\frac{\partial \tau^{*}}{\partial n} \frac{\partial n}{\partial F}=\frac{\partial \tau^{*}}{\partial n}\left(-\frac{\frac{\partial \Pi}{\partial F}}{\frac{\partial \Pi}{\partial n}}\right)
$$

where the sign of the derivative above depends on the parameters of the model according to:

$$
\operatorname{sign}\left(\frac{d \tau^{*}}{d F}\right)=\operatorname{sign}\left(\frac{m}{n}-\frac{1}{2} \frac{p s S}{p(1-p)(l-s)\left(\alpha_{1}-\alpha_{2}\right)}\right)
$$

This means that an increase in competition through a decrease in entry costs reduces the proportion of open-ended contracts if and only if expression (4) is positive. When this happens, an increase in competition always leads to a reduction in the proportion of open-ended contracts if expression (3) is negative. On the contrary, an increase in competition through a decrease in entry cost rises the proportion of open-ended contracts if and only if expression (4) is negative. In this case, an increase in competition always leads to a rise in the proportion of open-ended contracts. 


\section{Appendix B: The instrumental variable estimation us- ing the Spanish Labor Force Survey}

\section{Table B.1: List of industries included in the sample}



This is the list of industries for which there is information on the price-cost margin and on the Regulatory Impact so that they can be included in the instrumental variables estimation. 


\section{Table B.2: Estimation by instrumental variables displaying con- trols (Spanish Labor Force Survey)}

\begin{tabular}{|c|c|c|c|c|}
\hline & basic & year & sector & weighted \\
\hline Dep var: Transition to open-ended & $(1)$ & $(2)$ & $(3)$ & $(4)$ \\
\hline$\overline{\text { Age }}$ & $\begin{array}{c}0.0006 \\
(0.0002)^{* * *}\end{array}$ & $\begin{array}{l}0.0003 \\
(0.0002)\end{array}$ & $\begin{array}{c}0.0003 \\
(0.0002)\end{array}$ & $\begin{array}{c}0.0003 \\
(0.0002)\end{array}$ \\
\hline Married & $\begin{array}{l}-.002 \\
(0.004)\end{array}$ & $\begin{array}{l}0.002 \\
(0.004)\end{array}$ & $\begin{array}{l}0.001 \\
(0.004)\end{array}$ & $\begin{array}{c}0.00009 \\
(0.004)\end{array}$ \\
\hline Household head & $\begin{array}{c}0.012 \\
(0.004)^{* * *}\end{array}$ & $\begin{array}{c}0.012 \\
(0.004)^{* * *}\end{array}$ & $\begin{array}{c}0.013 \\
(0.005)^{* * *}\end{array}$ & $\begin{array}{c}0.013 \\
(0.005)^{* * *}\end{array}$ \\
\hline Spanish citizenship & $\begin{array}{l}0.024 \\
(0.017)\end{array}$ & $\begin{array}{c}0.035 \\
(0.016)^{* *}\end{array}$ & $\begin{array}{l}0.036 \\
(0.016)^{* *}\end{array}$ & $\begin{array}{c}0.033 \\
(0.017)^{* *}\end{array}$ \\
\hline High-school graduate & $\begin{array}{c}0.017 \\
(0.004)^{* * *}\end{array}$ & $\begin{array}{c}0.01 \\
(0.003)^{* * *}\end{array}$ & $\begin{array}{c}0.01 \\
(0.004)^{* * *}\end{array}$ & $\begin{array}{c}0.01 \\
(0.004)^{* * *}\end{array}$ \\
\hline University graduate & $\begin{array}{c}0.038 \\
(0.006)^{* * *}\end{array}$ & $\begin{array}{c}0.024 \\
(0.006)^{* * *}\end{array}$ & $\begin{array}{c}0.023 \\
(0.006)^{* * *}\end{array}$ & $\begin{array}{c}0.023 \\
(0.006)^{* * *}\end{array}$ \\
\hline Number of coworkers & $\begin{array}{c}0.0001 \\
(0.00005)^{* * *}\end{array}$ & $\begin{array}{c}0.0001 \\
(0.00004)^{* *}\end{array}$ & $\begin{array}{c}0.0001 \\
(0.00004)^{* *}\end{array}$ & $\begin{array}{c}0.0001 \\
(0.00004)^{* *}\end{array}$ \\
\hline $\begin{array}{l}\text { One year } \\
\text { fixed-term contract duration }\end{array}$ & $\begin{array}{c}0.185 \\
(0.007)^{* * *}\end{array}$ & $\begin{array}{c}0.181 \\
(0.007)^{* * *}\end{array}$ & $\begin{array}{c}0.181 \\
(0.007)^{* * *}\end{array}$ & $\begin{array}{c}0.181 \\
(0.007)^{* * *}\end{array}$ \\
\hline $\begin{array}{l}\text { Two years } \\
\text { fixed-term contract duration }\end{array}$ & $\begin{array}{c}0.039 \\
(0.005)^{* * *}\end{array}$ & $\begin{array}{c}0.028 \\
(0.006)^{* * *}\end{array}$ & $\begin{array}{c}0.028 \\
(0.006)^{* * *}\end{array}$ & $\begin{array}{c}0.029 \\
(0.006)^{* * *}\end{array}$ \\
\hline $\begin{array}{l}\text { Three years } \\
\text { fixed-term contract duration }\end{array}$ & $\begin{array}{c}0.29 \\
(0.016)^{* * *}\end{array}$ & $\begin{array}{c}0.273 \\
(0.016)^{* * *}\end{array}$ & $\begin{array}{c}0.273 \\
(0.016)^{* * *}\end{array}$ & $\begin{array}{c}0.271 \\
(0.016)^{* * *}\end{array}$ \\
\hline Wage differential & $\begin{array}{c}8.87 \mathrm{e}-08 \\
(1.50 \mathrm{e}-07)\end{array}$ & $\begin{array}{l}1.86 \mathrm{e}-07 \\
(1.10 \mathrm{e}-07)^{*}\end{array}$ & $\begin{array}{c}-3.85 \mathrm{e}-08 \\
(2.33 \mathrm{e}-07)\end{array}$ & $\begin{array}{c}-1.14 \mathrm{e}-08 \\
(2.30 \mathrm{e}-07)\end{array}$ \\
\hline Number of observations & 31737 & 31737 & 31737 & 31737 \\
\hline$R^{2}$ & 0.132 & 0.144 & 0.144 & 0.144 \\
\hline
\end{tabular}

The dependent variable is equal to one if the individual transitions from fixed-term to open-ended employment within a sector in a given year, and zero otherwise. The measure of competition is the pricecost margin multiplied by minus one. This is instrumented using the Regulatory Impact. The coefficients are marked with $*$ if the level of significance is between $5 \%$ and $10 \%$, ** if the level of significance is between $1 \%$ and $5 \%$ and $* * *$ if the level of significance is less than $1 \%$. The basic regression includes controls on individual and job characteristics (age, married, household head, dummies for region of residence, high-school graduate, university graduate, number of coworkers, dummies for duration of the fixed-term contract in years and quarter dummies). The second column adds year dummies to the basic regression. The third column includes, in addition to the variables in column 2, dummies for industry of employment. Finally, column 4 displays the results when individuals are weighted according to the ratio between the number of workers in their industry one year before the date of the interview and the number of workers in their industry at the time of the interview. The sample is drawn from the Spanish 
Labor Force Survey and includes men aged 16 to 64 with a fixed-term contract who have no seasonal jobs over the period 1993 to 2003. The price-cost margin is obtained from the Industrial Enterprise Survey. The Regulatory Impact is drawn from the OECD database. The industries included are listed in table B.1. Errors are clustered by sector-year. 


\section{Appendix C: The instrumental variable estimation us- ing Business Strategies Survey}

\section{Table C.1: List of industries included in the sample}

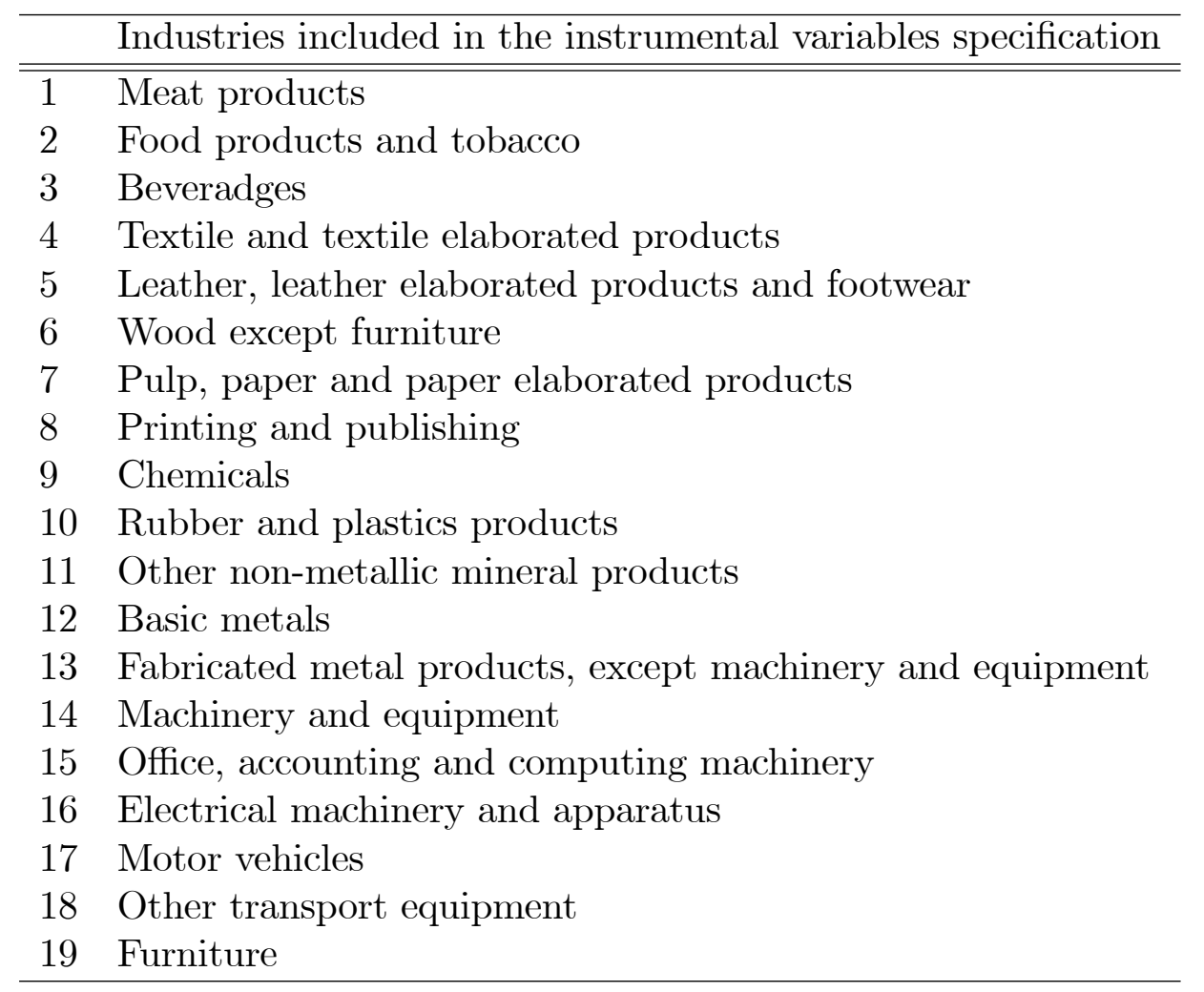

This is the list of industries for which there is information in the Business Strategies Survey. 


\section{Table C.2: Estimation by instrumental variables displaying con- trols (Business Strategies Survey)}

\begin{tabular}{|c|c|c|c|c|c|}
\hline & basic & year & sector & weights & firm fe \\
\hline Dep var: Proportion of open-ended & $(1)$ & $(2)$ & $(3)$ & $(4)$ & $(5)$ \\
\hline Number of workers & $\begin{array}{c}0.00002 \\
(2.99 \mathrm{e}-06)^{* * *}\end{array}$ & $\begin{array}{c}0.00002 \\
(2.94 \mathrm{e}-06)^{* * *}\end{array}$ & $\begin{array}{c}0.00002 \\
(2.81 \mathrm{e}-06)^{* * *}\end{array}$ & $\begin{array}{c}0.00002 \\
(2.93 \mathrm{e}-06)^{* * *}\end{array}$ & $\begin{array}{c}-.00002 \\
(8.99 \mathrm{e}-06)^{*}\end{array}$ \\
\hline Percentage of university grads & $\begin{array}{c}0.004 \\
(0.0005)^{* * *}\end{array}$ & $\begin{array}{c}0.004 \\
(0.0005)^{* * *}\end{array}$ & $\begin{array}{c}0.002 \\
(0.0005)^{* * *}\end{array}$ & $\begin{array}{c}0.002 \\
(0.0005)^{* * *}\end{array}$ & $(0.0005)^{* *}$ \\
\hline Percentage of high school grads & $\begin{array}{c}0.001 \\
(0.0002)^{* * *}\end{array}$ & $\begin{array}{c}0.001 \\
(0.0002)^{* * *}\end{array}$ & $\begin{array}{c}0.0006 \\
(0.0002)^{* * *}\end{array}$ & $\begin{array}{c}0.0006 \\
(0.0002)^{* *}\end{array}$ & $\begin{array}{l}0.0002 \\
(0.0003)\end{array}$ \\
\hline Percentage of part-time workers & $\begin{array}{l}0.0005 \\
(0.0004)\end{array}$ & $\begin{array}{c}0.0005 \\
(0.0004)\end{array}$ & $\begin{array}{c}0.0007 \\
(0.0004)^{*}\end{array}$ & $\begin{array}{c}0.0006 \\
(0.0004)^{*}\end{array}$ & $\begin{array}{c}0.003 \\
(0.0005)^{* * *}\end{array}$ \\
\hline Blue over white collar workers & $\begin{array}{c}0.001 \\
(0.0002)^{* * *}\end{array}$ & $\begin{array}{c}0.001 \\
(0.0002)^{* * *}\end{array}$ & $\begin{array}{c}0.0006 \\
(0.0003)^{* *}\end{array}$ & $\begin{array}{c}0.0006 \\
(0.0003)^{* *}\end{array}$ & $\begin{array}{l}0.0007 \\
(0.0006)\end{array}$ \\
\hline Wages over production & $\begin{array}{c}0.031 \\
(0.016)^{*}\end{array}$ & $\begin{array}{c}0.039 \\
(0.015)^{* * *}\end{array}$ & $\begin{array}{c}0.021 \\
(0.014)\end{array}$ & $\begin{array}{c}0.021 \\
(0.014)\end{array}$ & $\begin{array}{c}0.037 \\
(0.01)^{* * *}\end{array}$ \\
\hline Training expenditures per worker & $\begin{array}{c}0.00005 \\
(1.00 \mathrm{e}-05)^{* * *}\end{array}$ & $\begin{array}{c}0.00002 \\
(1.00 \mathrm{e}-05)\end{array}$ & $\begin{array}{c}8.80 \mathrm{e}-06 \\
(1.00 \mathrm{e}-05)\end{array}$ & $\begin{array}{c}9.43 \mathrm{e}-06 \\
(1.00 \mathrm{e}-05)\end{array}$ & $(1.00 \mathrm{e}-05)^{* * *}$ \\
\hline Worker compensations over production & $\begin{array}{c}0.552 \\
(0.039)^{* * *}\end{array}$ & $\begin{array}{c}0.588 \\
(0.04)^{* * *}\end{array}$ & $\begin{array}{c}0.549 \\
(0.039)^{* * *}\end{array}$ & $\begin{array}{c}0.55 \\
(0.038)^{* * *}\end{array}$ & $\begin{array}{c}0.118 \\
(0.033)^{* * *}\end{array}$ \\
\hline Merged firm & $\begin{array}{l}0.024 \\
(0.01)^{* *}\end{array}$ & $\begin{array}{c}0.024 \\
(0.01)^{* *}\end{array}$ & $\begin{array}{l}0.023 \\
(0.01)^{* *}\end{array}$ & $\begin{array}{l}0.022 \\
(0.01)^{* *}\end{array}$ & $\begin{array}{l}0.002 \\
(0.008)\end{array}$ \\
\hline Split firm & $\begin{array}{c}0.059 \\
(0.013)^{* * *}\end{array}$ & $\begin{array}{c}0.064 \\
(0.014)^{* * *}\end{array}$ & $\begin{array}{c}0.062 \\
(0.013)^{* * *}\end{array}$ & $\begin{array}{c}0.052 \\
(0.015)^{* * *}\end{array}$ & $\begin{array}{l}0.018 \\
(0.01)^{*}\end{array}$ \\
\hline R\&D over production & $\begin{array}{l}0.115 \\
(0.07)^{*}\end{array}$ & $\begin{array}{c}0.174 \\
(0.066)^{* * *}\end{array}$ & $\begin{array}{c}0.065 \\
(0.063)\end{array}$ & $\begin{array}{l}0.101 \\
(0.067)\end{array}$ & $\begin{array}{l}-.101 \\
(0.078)\end{array}$ \\
\hline Public capital over total capital & $\begin{array}{c}0.0007 \\
(0.00009)^{* * *}\end{array}$ & $\begin{array}{c}0.0008 \\
(0.0001)^{* * *}\end{array}$ & $\begin{array}{c}0.001 \\
(0.0001)^{* * *}\end{array}$ & $\begin{array}{c}0.0009 \\
(0.0001)^{* * *}\end{array}$ & $\begin{array}{c}0.0007 \\
(0.0002)^{* * *}\end{array}$ \\
\hline
\end{tabular}

The dependent variable is equal to proportion of open-ended over total contracted workers. The measure of competition is average price-cost margin in the industry multiplied by minus one. This is instrumented using the Regulatory Impact. The coefficients are marked with * if the level of significance is between $5 \%$ and $10 \%, * *$ if the level of significance is between $1 \%$ and $5 \%$ and $* * *$ if the level of significance is less than $1 \%$. The basic regression includes controls on workers and firm characteristics (number of workers, percentage of engineers and college graduates -separating long and short degrees-, percentage of workers with intermediate education, percentage of part-time permanent workers, ratio of blue over white collar workers, wages over production, workers training expenditures over production, worker compensations over production, merged firm, split firm, individual entrepreneur, R\&D over production and percentage of public capital). The second column adds year dummies to the basic regression. The third column includes, in addition to the variables in column 2, dummies for industry of employment. Column 4 displays the results when firms are weighted according to the ratio between the number of workers in their industry one year before the date of the interview and the number of workers in their industry at the time of the interview. Finally, column 5 is estimated using firm fixed-effects. The sample is drawn from the Business Strategies Survey and includes firms whose level of diversification does not exceed one industry as defined by the 2-digit classification over the period 1992 to 2006. The industries included are listed in table C.1. The price-cost margin is obtained from the Business Strategies Survey. The Regulatory Impact is drawn from the OECD database. Errors are clustered by sector-year. The F statistic of the excluded instrument in the first stage corresponding to the last column estimation is 24.05. This figure is clearly over the critical value provided by Stock and Yogo (2005) which indicates that the instrument is not weak. 


\section{Appendix D: Additional specifications}

\section{Table D.1: Business Strategies Survey results measuring compe- tition with the Concentration Index}

\begin{tabular}{lccccc} 
Estimation by ordinary least squares & & & & & \\
& basic & year & sector & weights & firm fe \\
\cline { 2 - 6 } Dep var: Proportion of permanent & $(1)$ & $(2)$ & $(3)$ & $(4)$ & $(5)$ \\
\hline - Concentration ratio & -.098 & -.113 & -.018 & -.012 & 0.002 \\
& $(0.03)^{* * *}$ & $(0.029)^{* * *}$ & $(0.03)$ & $(0.03)$ & $(0.027)$ \\
Number of observations & 17705 & 17705 & 17705 & 17705 & 17705 \\
\hline \hline
\end{tabular}

Estimation by instrumental variables

\begin{tabular}{lccccc} 
& basic & year & sector & weights & firm fe \\
\cline { 2 - 6 } Dep var: Proportion of permanent & $(1)$ & $(2)$ & $(3)$ & $(4)$ & $(5)$ \\
\hline - Concentration ratio & 0.137 & -.476 & -1.733 & -2.520 & -.761 \\
& $(0.153)$ & $(0.222)^{* *}$ & $(0.978)^{*}$ & $(2.078)$ & $(0.458)^{*}$ \\
Number of observations & 17705 & 17705 & 17705 & 17705 & 17417 \\
\hline \hline
\end{tabular}

The dependent variable is the proportion of open-ended over total contracted workers. The measure of competition is the average concentration ratio in the industry multiplied by minus one. This is instrumented using the Regulatory Impact. The coefficients are marked with * if the level of significance is between $5 \%$ and $10 \%,{ }^{* *}$ if the level of significance is between $1 \%$ and $5 \%$ and $* * *$ if the level of significance is less than $1 \%$. The basic regression includes controls on workers and firm characteristics (number of workers, percentage of engineers and college graduates -separating long and short degrees-, percentage of workers with intermediate education, percentage of part-time permanent workers, ratio of blue over white collar workers, wages over production, workers training expenditures over production, worker compensations over production, a dummy for merged firm, an indicator for split firm, a binary variable for individual entrepreneur, R\&D over production and percentage of public capital) The second column adds year dummies to the basic regression. The third column includes, in addition to the variables in column 2, dummies for industry of employment. Column 4 displays the results when firms are weighted according to the ratio between the number of workers in their industry one year before the date of the interview and the number of workers in their industry at the time of the interview. Finally, column 5 is estimated using firm fixed-effects. The sample is drawn from the Business Strategies Survey and includes firms whose level of diversification does not exceed one industry as defined by the 2-digit classification over the period 1992 to 2006. The industries included are listed in table C.1. The concentration ratio is obtained from the Business Strategies Survey. The Regulatory Impact is drawn from the OECD database. Errors are clustered by sector-year. The $\mathrm{F}$ test of the excluded instrument in the first stage corresponding to the last column estimation is 20.87 . This figure is clearly over the critical value provided by Stock and Yogo (2005) which indicates that the instrument is not weak. 


\section{Table D.2: Estimation by instrumental variables including switch- ers and assigning workers to the initial industry (Labor Force}

\section{Survey)}

\begin{tabular}{lccc} 
& basic & switchers & interaction \\
\cline { 2 - 4 } Dep var: Transition to open-ended & $(1)$ & $(2)$ & $(3)$ \\
\hline - Price-cost margin & -.703 & -.698 & -.694 \\
& $(0.32)^{* *}$ & $(0.318)^{* *}$ & $(0.319)^{* *}$
\end{tabular}

Switcher

$(0.005)^{* * *}$

$(0.013)^{* *}$

- Price-cost margin by Switcher

Number of observations

34000

34000

34000

$R^{2}$

0.137

0.138

0.138

The dependent variable is equal to one if the individual transitions from a fixed-term to open-ended employment within a sector in a given year, and zero otherwise. The measure of competition is the price-cost margin multiplied by minus one. The coefficients are marked with * if the level of significance is between $5 \%$ and $10 \%, * *$ if the level of significance is between $1 \%$ and $5 \%$ and $* * *$ if the level of significance is less than $1 \%$. The basic regression includes controls on individual and job characteristics (age, married, household head, dummies for region of residence, high-school graduate, university graduate, number of coworkers, dummies for duration of the fixed-term contract in years and quarter dummies), year and industry of employment dummies, as well as individual fixed-effects. The second column adds a indicator for switcher. The third column includes, in addition to the variables in column 2, an interaction of the measure of competition and an indicator for switcher. In all specifications, individuals are weighted according to the ratio between the number of workers in their industry one year before the date of the interview and the number of workers in their industry at the time of the interview. The sample is drawn from the Spanish Labor Force Survey and includes men aged 16 to 64 with a fixed-term contract who have no seasonal jobs over the period 1993 to 2003. The industries included are listed in table B.1. The price-cost margin is obtained from the Industrial Enterprise Survey. Errors are clustered by sector-year. 


\section{Table D.3: Quasi-experiment accounting for treatment intensity}

\section{(Labor Force Survey)}

\begin{tabular}{lccccc} 
& basic & year & sector & weighted & panel \\
\cline { 2 - 6 } Transition to open-ended & $(1)$ & $(2)$ & $(3)$ & $(4)$ & $(5)$ \\
\hline Barriers reduction & 0.03 & -.021 & -.036 & -.036 & -.120 \\
& $(0.013)^{* *}$ & $(0.013)$ & $(0.013)^{* * *}$ & $(0.013)^{* * *}$ & $(0.037)^{* * *}$ \\
Number of observations & 9667 & 9667 & 9667 & 9667 & 7235 \\
$R^{2}$ & 0.162 & 0.167 & 0.168 & 0.168 & 0.252 \\
\hline \hline
\end{tabular}

The dependent variable is equal to one if the individual transitions from fixed-term to open-ended employment within a sector in a given year, and zero otherwise. The measure of competition the interaction of a dummy for working in a treated sector in the post-treatment period with the proportion of removed legal barriers to entry in each sector according to the OECD. The coefficients are marked with * if the level of significance is between $5 \%$ and $10 \%,{ }^{* *}$ if the level of significance is between $1 \%$ and $5 \%$ and $* * *$ if the level of significance is less than $1 \%$. The basic regression includes controls on individual and job characteristics (age, married, household head, dummies for region of residence, high-school graduate, university graduate, number of coworkers, dummies for duration of the fixed-term contract in years and quarter dummies). The second column adds year dummies to the basic regression. The third column includes, in addition to the variables in column 2, dummies for industry of employment. Column 4 displays the results when individuals are weighted according to the ratio between the number of workers in their industry one year before the date of the interview and the number of workers in their industry at the time of the interview. Finally, column 5 adds individual fixed-effects. The sample is drawn from the Spanish Labor Force Survey and comprises men aged 16 to 64 with a fixed-term contract who have no seasonal jobs over the period 1993 to 2003. The industries included are energy, rail\&road, post\&telecom, airline and retail. The airline and retail industries serve as controls. Errors are clustered by sector-year. 


\section{Table D.4: Estimation by instrumental variables and quasi-experiment with two dimensional cluster (Labor Force Survey)}

\begin{tabular}{lcccc} 
Estimation by instrumental variables & \multicolumn{2}{c}{ year } & sector & weighted \\
\cline { 2 - 5 } Dep var: Transition to open-ended & $(1)$ & $(2)$ & $(3)$ & $(4)$ \\
\hline - Price-cost margin & 0.658 & 0.093 & -.802 & -.771 \\
& $(0.169)^{* * *}$ & $(0.056)^{*}$ & $(0.277)^{* * *}$ & $(0.327)^{* *}$ \\
Number of observations & 31043 & 31043 & 31043 & 31043 \\
$R^{2}$ & 0.135 & 0.148 & 0.148 & 0.148 \\
\hline \hline
\end{tabular}

Quasi-experiment

\begin{tabular}{lccccc} 
& basic & year & sector & weighted & ind fe \\
\cline { 2 - 6 } Dep var: Transition to open-ended & $(1)$ & $(2)$ & $(3)$ & $(4)$ & $(5)$ \\
\hline Energy after 1997 & 0.02 & -.026 & -.046 & -.050 & -.197 \\
& $(0.015)$ & $(0.009)^{* * *}$ & $(0.019)^{* *}$ & $(0.025)^{* *}$ & $(0.029)^{* * *}$ \\
Rail\&road after 1998 & 0.015 & -.010 & -.022 & -.021 & -.040 \\
& $(0.012)$ & $(0.01)$ & $(0.009)^{* *}$ & $(0.008)^{* *}$ & $(0.007)^{* * *}$ \\
Post\&telecom after 1999 & 0.032 & -.026 & -.021 & -.025 & -.127 \\
& $(0.019)^{*}$ & $(0.017)$ & $(0.017)$ & $(0.021)$ & $(0.067)^{*}$ \\
Number of observations & 9623 & 9623 & 9623 & 9623 & 7191 \\
$R^{2}$ & 0.163 & 0.169 & 0.169 & 0.169 & 0.255 \\
\hline \hline
\end{tabular}

The dependent variable is equal to one if the individual transitions from fixed-term to open-ended employment within a sector in a given year, and zero otherwise. In the first panel, the measure of competition is the price-cost margin multiplied by minus one. This is instrumented using the Regulatory Impact. In the second panel, the measures of competition are a dummy for working in the energy sector in 1997 or after, a dummy for working in the rail\&road sector in 1998 or after, and a dummy for working in the post\&telecom sector in 1999 or after. The coefficients are marked with * if the level of significance is between $5 \%$ and $10 \%, * *$ if the level of significance is between $1 \%$ and $5 \%$ and $* * *$ if the level of significance is less than $1 \%$. The basic regression includes controls on individual and job characteristics (age, married, household head, dummies for region of residence, high-school graduate, university graduate, number of coworkers, dummies for duration of the fixed-term contract in years and quarter dummies). The second column adds year dummies to the basic regression. The third column includes, in addition to the variables in column 2, dummies for industry of employment. Column 4 displays the results when individuals are weighted according to the ratio between the number of workers in their industry one year before the date of the interview and the number of workers in their industry at the time of the interview. Finally, column 5 in the second panel adds individual fixed effects. The sample is drawn from the Spanish Labor Force Survey and includes men aged 16 to 64 with a fixed-term contract who have no seasonal jobs over the period 1993 to 2003 . The price-cost margin is obtained from the Industrial Enterprise Survey. The Regulatory Impact is drawn from the OECD database. The industries included in the estimation 
by instrumental variables are listed in table B.1. The industries in the quasi-experiment are energy, rail\&road, post\&telecom, airline and retail. The airline and retail industries serve as controls. Errors are clustered in the sector-year and individual dimensions. The F statistic of the excluded instrument in the first stage corresponding to the last column of the IV estimation is 24.05. This figure is clearly over the critical value provided by Stock and Yogo (2005) which indicates that the instrument is not weak. 